\title{
How to circumvent adversity? Refugee-entrepreneurs' resilience in the face of substantial and persistent adversity ${ }^{\text {it }}$
}

\author{
Dean A. Shepherd ${ }^{\mathrm{a}, *}$, Fouad Philippe Saade ${ }^{\mathrm{b}}$, Joakim Wincent ${ }^{\mathrm{b}, \mathrm{c}}$ \\ ${ }^{a}$ University of Notre Dame, Mendoza College of Business, Notre Dame, IN, United States of America \\ ${ }^{\mathrm{b}}$ Hanken School of Economics, Helsinki, Finland \\ ${ }^{\mathrm{c}}$ Institute of Technology Management, University of St Gallen, St Gallen, Switzerland
}

\section{E X E C U T I V E S U M M A R Y}

People face adverse events in a variety of forms. Some individuals are resilient to adverse events in that they are able to maintain positive functioning while others experience considerable disruption. In explaining heterogeneity in resilience, research has emphasized people's resource endowments and pre-adversity organizing prior to the adverse events as well as people's cognitive and behavioral responses to such events. Therefore, for most resilience studies, adversity is an event. Although it is critically important to understand resilience to these short- to mediumterm adverse events, there is a need to understand resilience over an extended period. In this regard, we focus on Palestine refugees who were born in refugee camps and as adults have known nothing other than being a refugee.

When it comes to substantial and persistent adversity, entrepreneurial action likely plays a central role in resilience to such adversity. To explore these relationships, we conducted an extensive data-collection effort over 15 months on refugee entrepreneurs (in refugee camps and not in camps), including 110 interviews. We find the importance of direct, indirect, and recursive relationships among actions (i.e., entrepreneurial action and integration activities), multiple identities, and resilience outcomes under conditions of substantial and persistent adversity. Furthermore, we find important differences between refugee entrepreneurs who live in refugee camps and those who live outside these camps-differences in affiliation, language use, and social capital development-which enable those refugee entrepreneurs living outside the refugee camps to achieve resilience outcomes not accessible to those living inside the camps.

Overall, this study makes a number of contributions to the entrepreneurship literature. First, research has investigated resilience in terms of resources, endowments, and capabilities before an adverse event. The implicit assumptions in this research are that capabilities matter and that adversity has a beginning and subsides over time. In this study, we focus on resilience outcomes in the context of refugees facing substantial adversity over a substantial period and extend the capability argument of resilience in the following ways: (1) the "social" capability for resilience, not as an endowment but created through activities that build a social basis for resilience outcomes, (2) social integration activities are initiated and facilitated by engaging in entrepreneurial action with non-similar others, and (3) resilience outcomes help individuals both engage in integration activities and build a social capability of resilience. Therefore, in the context of substantial and persistent adversity, refugee entrepreneurs need to act in order to build (rather than simply deploy) their social capability for resilience outcomes.

Second, resilience has been explored as either a process or as an outcome. In this study, we find that resilience outcomes are both a consequence and an antecedent of entrepreneurial action-a mutually dependent relationship. Specifically, we find the dimensions of resilience outcomes to include proactive problem solving, moral gains as a broader purpose in life, self-reliance, realistic optimism, and multiple sources of belonging. What is interesting is that these outcomes are also important inputs to entrepreneurial action and the resilience process.

\footnotetext{
The authors would like to thank Oana Branzei and three anonymous reviewers for their helpful recommendations and Ali Ferguson for help in copyediting the manuscript.

* Corresponding author.

E-mail addresses: Dshepherd@indiana.edu (D.A. Shepherd), philippe.saade@hanken.fi (F.P. Saade), joakim.wincent@hanken.fi (J. Wincent).
} 
Finally, there has been an important stream of research on the role of identity in recovery from adversity. We find that refugee entrepreneurs' actions provide a basis for changing the mix of their multiple identities. Therefore, we enrich the entrepreneurship identity literature through the insight that in this persistently adverse context, the relationship between entrepreneurial action and identity is not one way and static but bidirectional and dynamic. Furthermore, over and above refugee entrepreneurs' prosocial motivation of compassion, we find a new form of prosocial motivation for entrepreneurial action — the motivation to promote solidarity: "You are not alone; we are in this together as part of a broader purpose in life."

\section{Introduction}

Adversity abounds. There is adversity in the aftermath of disaster events (e.g., Williams and Shepherd, 2016a; Van der Vegt et al., 2015), terrorism (Branzei and Abdelnour, 2010), and other instances when people experience considerable resource loss (Lanivich, 2015; Mone et al., 1998). People can face adversity from losing their work-related identities (Conroy and O'Leary-Kelly, 2014; Shepherd and Williams, 2018) as well as from witnessing death or being injured at work (Grant and Wade-Benzoni, 2009; Maitlis, 2009). Refugees, in particular, face extreme adversity from the disasters of war and the accompanying death and injury (Tay and Silove, 2017). As a result, these individuals have to leave their homelands, which generates further loss and separates family members and friends (Betancourt et al., 2015).

Although adversity in general (Piccardi et al., 2016) and in the refugee context specifically (McGregor et al., 2015; Soykoek et al., 2017) can lead individuals to experience personal dysfunction (e.g., depression and post-traumatic stress disorder [PTSD] symptoms), such a response to adversity is not always the most common. Some (and even the majority of) individuals are resilient; that is, they can maintain (or quickly regain) positive personal functioning in the face of adversity (Bonanno, 2004, 2005). For example, in a study of the aftermath of the 9/11 terrorist attack on the World Trade Center in New York City, Bonanno et al. (2006) found that of a sample of New York area residents $(n=2752), 65.1 \%$ demonstrated resilience after the attack. Similar results have been found for individuals whose spouse has died (Bonanno et al., 2005), those who have experienced traumatic injury (de Roon-Cassini et al., 2010), and those who are refugees (Hooberman et al., 2010). In explaining why some individuals are more resilient than others, research has emphasized the resource endowments people possess prior to adverse events (e.g., Bonanno et al., 2010; Hobfoll, 1989; Sutcliffe and Vogus, 2003), pre-adversity organizing to reduce vulnerability (Roberts, 1990; Drabek and McEntire, 2003; Vogus and Sutcliffe, 2007), and both cognitive (Dewald and Bowen, 2010; Lengnick-Hall and Beck, 2005; Weick, 1993) and behavioral (Lengnick-Hall and Beck, 2005; Rahmandad and Repenning, 2016; Weick, 1993) responses to crises. For most studies of resilience, adversity has a beginning (e.g., an event) and diminishes over time (for a review, see Williams et al., 2017).

In this study, we note that alongside these conditions of short- to medium-term adversity, there is a need to understand resilience over an extended period. In particular, we need greater clarity about resilience when there is no period "before adversity" to prepare and reduce vulnerability. For example, Rami Saaf is a 34-year-old Palestine refugee who was born and still lives in the Beddawi refugee camp north of Lebanon. He characterized the camp as a place "where raw sewage and water leak onto (electric) wires" (Khoury, 2017). These conditions are adverse, existed before his birth, and are likely to continue for an extended period.

Entrepreneurial action is both the antecedent to and consequence of resilience outcomes. Many factors drive entrepreneurial action, including opportunity beliefs (McMullen and Shepherd, 2006), access to resources (George, 2005), and entrepreneurial passion (Cardon et al., 2009). However, when it comes to adversity, entrepreneurial action becomes critically important, and identity becomes a highly salient issue (Powell and Baker, 2014). That is, entrepreneurs' identities drive their perceptions of and responses to adversity such that those who perceive an adverse situation as an opportunity embrace adversity, those who perceive the situation as a challenge try to counter adversity, and those who perceive the situation as a threat attempt to accommodate adversity (Powell and Baker, 2014). Thus, identity plays a central role in entrepreneurial action under adversity, so we focus on this construct in our exploration. Our resilience approach to refugee entrepreneurs enables us to extend this identity view of interpreting and responding to adversity by conceptualizing the multiple identities underlying an entrepreneurial action perspective of resilience outcomes. Multiple identities relate to the identities associated with an individual's different roles (Brook et al., 2008; Thoits, 1983), such as professor, father, husband, and softball coach. Managing these multiple identities can be challenging, especially when one's identities conflict (Pratt and Foreman, 2000; Shepherd and Haynie, 2009), such as in the context of high adversity (Howells and Fletcher, 2015; Powell and Baker, 2014). When facing adversity, an individual's identity (or multiple identities) is threatened (Petriglieri, 2011) and entrepreneurial action may provide a vehicle for identity change (Haynie and Shepherd, 2011; Powell and Baker, 2014).

In this study, we focus on the persistent and harsh adversity facing refugee entrepreneurs who are Palestine refugees in Lebanon. By refugee entrepreneur, we simply mean an individual whose primary source of income comes from "the activity of organizing, managing, and assuming the risks of business or enterprise" (Shane, 2008: 2) ${ }^{1}$ and who is a refugee. A refugee is an individual who as a result of events occurring before 1 January 1951 and owing to well-founded fear of being persecuted for reasons of race, religion, nationality, membership of a particular social group or political opinion, is outside the country of his nationality and is unable or, owing to such fear, is unwilling to avail himself of the protection of that country; or who, not having a nationality and being outside

\footnotetext{
${ }^{1}$ Although some definitions of entrepreneur emphasize the creation of a new organization (Gartner, 1988), that is not a requirement of the current definition. All but one of the entrepreneurs in our sample created the organization they are now organizing, managing, and bearing the risk of.
} 
the country of his former habitual residence as a result of such events, is unable or, owing to such fear, is unwilling to return to it. (UNHCR, 2011: 10; see also Hutchinson and Dorsett, 2012) ${ }^{2}$

Indeed, refugees face considerable adversity that constrains their behaviors. First, refugees living in camps are exposed to overcrowding, extreme poverty (Khalil, 2011; Al-Khatib et al., 2005; Halabi, 2004), squalor and unhygienic living conditions (Cutler, 2016), low literacy rates (Khalil, 2011), and death resulting from war (e.g., 78\% of residents of Lebanon's Shatila refugee camp have experienced a war-exposure event) (Segal et al., 2018). Second such adversity can lead some people to experience dysfunction, including emotional distress, PTSD, anxiety, and depression (Steel et al., 1999; Steel et al., 2002; Ssenyonga et al., 2013). Third, despite the adversity faced, many refugees do not display dysfunction but are resilient in the face of this adversity (Hutchinson and Dorsett, 2012; Powell et al., 2003; Papadopoulos, 2001). Finally, while identity can play a role in explaining resilience to adversity (Powell and Baker, 2014), issues related to identity for refugees are more complicated (vis-à-vis non-refugees) regarding identifying with "birth" and "residing" country. Therefore, we ask the following: how do refugee entrepreneurs develop and manage their multiple identities in the face of substantial and persistent adversity, and to what affect?

We conducted an extensive data-collection effort over 15 months on refugee entrepreneurs (in refugee camps and not in camps), including 110 interviews. Because we were primarily dealing with illegally run businesses, there were few physical documents available, so we relied on extensive interviews and field notes. Through our analysis, we identify a pattern of intertwinement of adversity and refugee entrepreneurs' identity-related issues, which triggers (informal) entrepreneurial action that directly contributes to (and reflects) their resilience to persistent and harsh living conditions. We also find that for some refugees, their entrepreneurial action indirectly influences resilience outcomes through host-country integration efforts-namely, identifying as a local, living as a local, speaking as a local, marrying a local, and connecting with locals (i.e., with citizens of the host country). Resilience outcomes reflect individuals' positive functioning in the face of adversity, which further enhances refugee entrepreneurs' integration efforts and entrepreneurial action but does not address the level of adversity.

This study's findings contribute to research on entrepreneurship by extending our understanding how refugees' entrepreneurial action in the context of adversity impact (both directly and indirectly) different dimensions of resilience outcomes. By highlighting a context of substantial and persistent adversity, we gain further understanding of the impact of entrepreneurial action alongside (what seems to be) an unsolvable problem-namely, achieving long-term resilience outcomes without necessarily diminishing the objective adversity. By highlighting the mechanisms underlying some refugees' efforts to integrate with locals, we gain a deeper understanding of the role of multiple identities in a highly constraining environment-an approach that expands the boundaries of our knowledge of the entrepreneur identity map and positive functioning under persistent resilience. Although research on resilience has focused on the utilization of slack capabilities—namely, cognitive, relational, and emotional capabilities (Hobfoll, 2011; Lengnick-Hall and Beck, 2005; Sutcliffe and Vogus, 2003)—when exploring entrepreneur refugees in persistent adversity, we find that identity management stands out in our data, thus enabling novel theorizing. Finally, by explaining how the underlying dynamics of entrepreneurial action and integration interact to influence resilience outcomes (and vice versa), the current study may be useful for understanding entrepreneurial action as a means of "dealing with" highly constrained contexts.

\section{Theoretical background}

The theoretical background for this study is positive psychology (Seligman and Csikszentmihalyi, 2014; Sheldon and King, 2001) and positive organizational scholarship (Cameron and Dutton, 2003; Youssef and Luthans, 2007) with a focus on resilience (Masten and Reed, 2002; Sutcliffe and Vogus, 2003). Resilience refers to "the process by which an actor (individual, organization, or community) builds and uses its capability endowments to interact with the environment in a way that positively adjusts and maintains functioning prior to, during, and following adversity" (Williams et al., 2017: 742). By adversity, we refer to "an unfortunate event or circumstance or the state of serious and continued difficulty" (Tian and Fan, 2014: 252). Despite the common assumption that all people face dysfunction in response to adversity (e.g., a disaster, death of a loved one, or another form of major loss), research has found that a substantial number of people do not experience such a reaction; rather, they maintain positive functioning (Bonanno, 2004, 2005; Bonanno et al., 2005, 2006)—high emotional, psychological, and social well-being (Keyes and Lopez, 2002) and can experience personal growth from a tragic event (Maitlis, 2009; Vough and Caza, 2017). Not surprisingly, scholars have turned their attention toward explaining this heterogeneity in response to adversity.

Theoretical explanations of more or less resilient outcomes include studies on resource endowments, pre-adversity organizing, and responses to adversity. Resource endowments include an individual's trait-based attributes (Luthar et al., 2000) and capability endowments that are cognitive (Lengnick-Hall and Beck, 2005; Thomas et al., 1993), behavioral (Bigley and Roberts, 2001; Weick et al., 2008), and emotional (Amabile et al., 2005; Fredrickson, 1998; Shepherd and Williams, 2014). Research on pre-adversity organizing has focused on reducing vulnerability (for a review, see Drabek and McEntire, 2003, Weick et al., 2008; Van der Vegt et al., 2015) and preparing to restore positive functioning (e.g., high-reliability organizations [Roberts, 1990; Wildavsky, 2017; Weick et al., 1999). Research on responding to major disturbances has focused on cognitive (e.g. Dewald and Bowen, 2010; Hobfoll, 2011; Lengnick-Hall and Beck, 2005) and behavioral responses to adversity (Lengnick-Hall and Beck, 2005; Weick, 1993), including entrepreneurial action in response to war-torn Afghanistan (Bullough et al., 2014), an earthquake in Haiti (Williams and Shepherd,

\footnotetext{
2 "Lebanon is not a signatory to either the Convention Relating to the Status of Refugees of 1951 or the 1967 Protocol Relating to the Status of Refugees, so the safeguards and guarantees of these documents are not legally binding on Lebanon with regard to its Palestinian population" (Khalil, 2010: 9, as cited in Said, 1999: 325).
} 
2016a), bushfires in Australia (Shepherd and Williams, 2014; Williams and Shepherd, 2016b), and the Great Recession in America (Powell and Baker, 2014). Much of the research on resilience has focused on adversity as an event (created at a point in time or the result of an accumulation of factors that reach a tipping point). However, there has been a recent call to expand our exploration of time as it relates to the types of adversity we investigate. Williams et al. (2017: 753) noted that "adversity is heterogeneous; some challenges are triggered quickly, evolve rapidly, and are short in duration, whereas other challenges emerge slowly, evolve more gradually, and are extended over time." For example, as Aleinikoff (2015: 2) noted,

The relief-to-development mantra can make sense in cases of a natural disaster; when a temporary shock has taken a community off its normal development course. And this logic links to the mot du jour: "resilience." A resilient society is able to withstand shock and begin rebuilding more quickly. But these concepts are more difficult to apply in situations of long-term displacement. Refugee camps and settlements persist in host communities, usually as isolated, unproductive islands sustained largely by the international community_or neglected altogether. Host states are not likely to include refugees in their national development plans, meant for their own citizens, and are not likely to want international funders to divert development dollars to non-nationals. As a result, international assistance to displaced communities continues to be sourced from "humanitarian" baskets no matter how long the displacement continues.

While research on refugee entrepreneurship has acknowledged the adversity that refugees face (Refai et al., 2018), the focus has been on the benefits gained from refugees engaging in entrepreneurial action in terms of their integration in the local community (Wauters and Lambrecht, 2008) as a pathway to self-sufficiency (Fong et al., 2007), belongingness (Bizri, 2017), and a boost to domestic entrepreneurship (Wauters and Lambrecht, 2006). Although there have been numerous anecdotal stories of refugee entrepreneurs displaying resilience (Freiling and Harima, 2019; Palalić et al., 2019), scholars have not explored the nature of the adversity they face, the nature of their resilience outcomes, or the way entrepreneurial action operates under this adversity to generate different resilience outcomes. Furthermore, although we know that entrepreneurial action can facilitate positive outcomes in the face of adverse events (e.g., recessions [Powell and Baker, 2014], bushfires [Shepherd and Williams, 2014; Williams and Shepherd, 2016a], and earthquakes [Williams and Shepherd, 2016b), we do not have a good understanding of the role of entrepreneurial action in generating resilience outcomes for the individual facing adversity (e.g., see calls for entrepreneurship research that is more contextualized [Welter, 2011], especially in rural and other depleted communities [Jack and Anderson, 2002; Korsgaard et al., 2016]) or when the adversity is persistent. Indeed, some contexts of high adversity have existed for so long that for some individuals, there is no "pre-adversity" stage, and the forces of adversity are so persistent that there are no solutions to the problem in sight.

Knight (1983) used the term refugee entrepreneurs metaphorically to explore individuals who use entrepreneurial action to escape the "limitations and constraints" of their former lives (Ray, 1993: 96). We investigate refugee entrepreneurs literally to gain a deeper understanding of how individuals engage entrepreneurial action to escape the limits and constraints of their lives embedded in substantial and persistent adversity. Therefore, we are interested in understanding how entrepreneurial action affects resilience in contexts of substantial and persistent adversity, and we generate that understanding by exploring how refugee entrepreneurs manage the "limitations and constraints" of their lives to achieve positive resilience outcomes in what we may consider a helpless situation.

From an identity theory perspective (Ashforth, 2000; Burke and Stets, 2009; Stryker, 1980), individuals consider their lives in terms of the multiple role identities they create and maintain through interactions with the social structure. From this perspective, an identity refers to the various meanings attached to an individual by him- or herself and others (Gecas, 1982; Ibarra, 1999) as the individual enacts specific roles. Role identities are "socially constructed definitions of self-in-role (this is who a role occupant is), consisting of core or central features and peripheral features. Core features tend to be important, necessary, or typical characteristics of the identity and more defining of the identity" (Ashforth et al., 2000: 475). Thus, individuals' roles set standards that guide expectations, meaning, and behaviors (Stryker and Burke, 2000; Thoits, 1986) such that individuals focus on achieving a match between the meanings associated with a particular role and the behavior they enact when in that role and engaging with others (Burke, 1980; Burke and Reitzes, 1981). When entrepreneurs manage their multiple identities to avoid or resolve identity conflict around their different roles, they are likely to achieve greater psychological well-being (Shepherd and Haynie, 2009).

\subsection{Research context}

We chose the extreme context of the Palestine refugee situation in Lebanon, a context of persistent and substantial adversity in which "long-term dependency for forced migrants, coupled with a lack of membership in a state, denies millions of persons a present and a future" (Aleinikoff, 2015: 3). This extreme context enables theory building, but we also realize there is controversy around the topic. Our purpose is not to contribute to or resolve this controversy.

Palestine refugees have been living in Lebanon for 70 years, and approximately $90 \%$ of the current refugees were born in Lebanon (International Labor Organization [ILO]; Committee for the Employment of Palestinian Refugees in Lebanon [CEP], 2011). Although it difficult to obtain a precise number of Palestine refugees, the latest census conducted in 2017 estimates that 174,422 Palestinians reside in Lebanon (Lebanese Palestinian Dialogue Committee [LPDC], Central Administration of Statistics, and Palestinian Central Bureau of Statistics, 2018). Of these refugees, 63\% live in 12 official camps under the United Nations Relief and Works Agency (UNRWA) administration, and the remaining 37\% live in 39 refugee agglomerations (i.e., gatherings) and elsewhere in cities and towns throughout Lebanon (Chaaban et al., 2016).

Palestine refugees in Lebanon face many hardships. First, Palestinians do not have the right of citizenship in Lebanon (Knudsen, 2009). Instead, Lebanese authorities issue refugee documents to (most) Palestinians in Lebanon based on their registration with 
UNRWA (Shiblak, 1996). Second, Palestine refugees lack freedom of mobility. Indeed, the Lebanese Armed Forces strictly controls the movement of individuals within (Hanafi et al., 2012) and outside the country (Suleiman, 2010). Third, Palestine refugees have limited employment prospects. Although Lebanese law allows Palestine refugees to practice some professions, they are prohibited from employment in 36 syndicated professions (Chaaban et al., 2016; Saghieh and Nammour, 2015). Indeed, only 2\% of working Palestinians have legal work permits (El-Nashif and El-Khoury, 2012). Fourth, most Palestine refugees are denied access to government services, such as healthcare, education, and social benefits, and must rely on UNRWA, non-government organizations (NGOs), and the Palestinian Red Cross for these services (Suleiman, 2010). In recent years, these service providers have been underfunded, overcrowded, and underperforming (Khalil, 2011; Hanafi and Tiltnes, 2008); this lack of basic services adds to the refugees' hardships.

\subsection{Research approach and methods}

Recent research has used qualitative approaches to investigate resilience to adversity in the entrepreneurial context (e.g., Powell and Baker, 2014, 2017; Shepherd and Williams, 2014; Williams and Shepherd, 2016a). Specifically, we used an abductive approach (Peirce et al., 1958) to explore the richness of the topic. By abductive, we mean that we "developed our theoretical ideas alongside increasingly accurate mapping of the case" (consistent with the method used in Monin et al. (2013: 261) and Nag et al. (2007)).

\subsection{Data-collection procedures and sources}

We primarily relied on semi-structured interviews to gather rich data given our research question, but we also used field notes to triangulate and provide additional content.

Sampling and Access to Respondents. During the pre-fieldwork phase, we discovered that Palestine refugees were reluctant to talk openly about their lives and livelihoods to (non-Palestinian) outsiders. Also, many of these refugees squarely refused to be recorded. To resolve both of these problems, we partnered with one of our informants, a Palestinian-Jordanian filmmaker who-owing to his trade-had a substantial network within the Palestine refugee community in Lebanon. We then used a snowball sampling approach because this approach has been shown to be an efficient strategy for sampling from hard to reach populations (Perez et al., 2013) and has been "widely used in qualitative sociological research" (Biernacki and Waldorf, 1981: 141). Snowball sampling refers to "a recruitment technique wherein existing participants are encouraged in turn to refer members of their social network to the study" (Browne, 2005; Perez et al., 2013). Our selection of entrepreneurs was guided by our definition of "Palestine refugee entrepreneur" as any Palestine refugee who is officially registered with UNRWA in Lebanon; resides only in Lebanon; does not hold any passport or Lebanese citizenship; and whose primary source of income comes from "the activity of organizing, managing, and assuming the risks of business or enterprise" (Shane, 2008: 2). We located additional respondents through introductions from international and local NGOs that worked on empowering refugee entrepreneurship in Lebanon. Identifying respondents and planning interviews took four months, during which we identified 60 potential respondents. Of those, $47 \%(n=28)$ agreed to participate, which is high considering that most Palestine refugee entrepreneurs in Lebanon operate illegally.

\subsubsection{Interviews}

We collected data through 110 interviews conducted over a period of 15 months. In total, we interviewed 28 entrepreneurs. To triangulate the information from the refugee entrepreneurs, we also interviewed 25 spouses or family members (one for each of the 25 married entrepreneurs [three entrepreneurs were unmarried]), 28 customers (one for each of the 28 entrepreneurs), and six representatives from international and local NGOs. To gain an understanding of the context from the perspective of citizens of the host country, we interviewed 26 Lebanese citizens chosen at random in three different types of neighborhoods in Beirut (the capital of Lebanon): (1) a neighborhood supportive of the Palestinians, (2) a neighborhood hostile toward the presence of the Palestinians, and (3) a neighborhood of mixed attitudes toward the Palestinians. We partnered with one of our informants, a Palestinian who is fluent in the Lebanese and Palestinian dialects, to conduct the interviews in the language preferred by the interviewees. Thanks to this partnership, we were able to develop trusting relationships with the respondents, who were then more inclined to provide in-depth and revelatory accounts of their private and work lives and introduce us to their spouses and customers for supplemental interviews.

When conducting the interviews with the entrepreneurs, we relied on a semi-structured approach, giving each respondent considerable scope to tell his or her story. The semi-structure consisted of questions in five broad categories: (1) personal profile, including questions like "Where are you from," "Where were you born, and where were your parents born," "Where do you live now, and have you ever lived in a refugee camp," and "How would you describe life in the refugee camp"; (2) identity and sense of belonging, including questions like "What is your lineage, and how important is it to you," "How would you describe yourself in terms of nationality or ethnicity," "Do you consider yourself a Palestine refugee," "To what extent do you feel Palestinian and/or feel Lebanese," "Do you have family ties with the Lebanese," and "Do you consider yourself an entrepreneur"; (3) business venture and entrepreneurial activities, including questions like "Why did you choose this path of entrepreneurship," "Given the chance to be employed, would you choose employment over entrepreneurship," "Can you tell me about your business," and "What do you do in terms of marketing to convince the Lebanese to buy your products"; (4) impact of the regulatory environment, including questions like "Do you have Lebanese employees and/ or Palestinian employees in your business," "Do you think the regulations are fair for Palestinian entrepreneurs," "Which regulations are the most burdensome," and "How do you feel about this unfairness"; and (5) feelings of social integration (or not), including questions like "What are the costs and benefits to you and your family of having your own business," "Do you deal with other nationalities," "Is there any contact with other communities," and "Do you actively hide your identity from customers or do you reveal it?" 
We applied a similar approach for our interviews with customers, including a semi-structure with questions related to the customer's personal profile, the entrepreneur's business, the entrepreneur's characteristics, the entrepreneur's degree of social integration, and the impact of the regulatory environment. As for our interviews with the spouses (or close friend if the entrepreneur was not married), the semi-structure categories included the spouse's personal profile; the spouse's assessment of the entrepreneur's business; identity and sense of belonging; and the spouse's assessment of the impact of the regulatory and social environments on him- and herself, the entrepreneur, and the entrepreneur's business. Our interviews with the NGO representatives used a semi-structure with

\section{First-Order Categories Second-Order Themes Aggregate Dimensions}

Preclude Palestine refugees from the legal protection given to other refugees; lack of enforcement of UN; and lack of enforcement of multiple Arab League resolutions regarding civil and economic rights of Palestine refugees

Preclude Palestine refugees from: employment and selfemployment, property ownership and inheritance rights, and multiple civil and economic rights

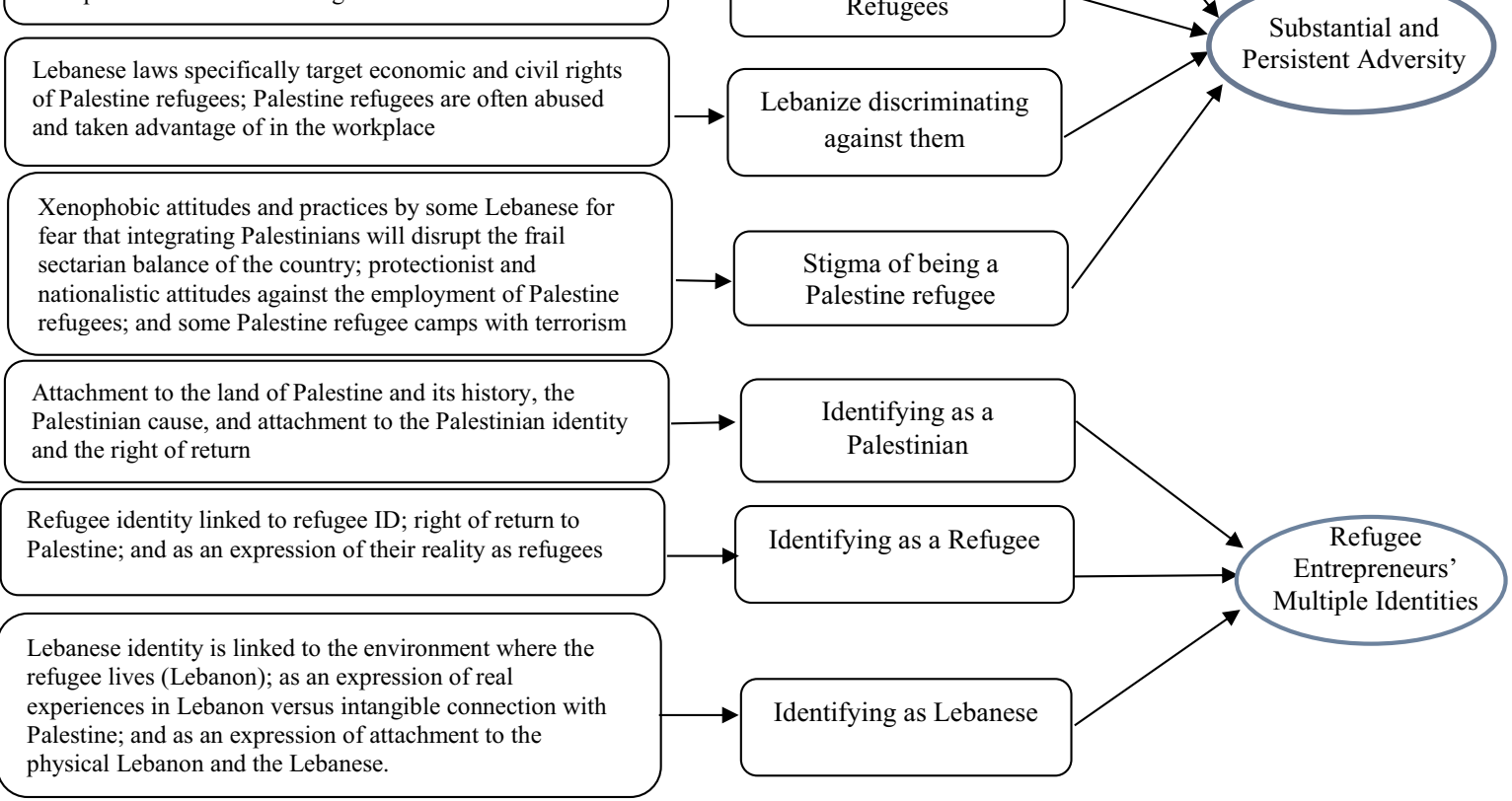

Speaking the Lebanese dialect, adopting the culture and interacting with it, and not being identifiable as Palestinian

Seeking better social and living conditions; escaping socia and security constraints; and seeking better economic opportunities.

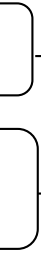

Speaking the Lebanese dialect; adopting the culture and interacting with it; and not being identifiable as Palestinian

Forming deep and durable bonds with Lebanese; receiving support and overcoming legal restrictions through Lebanese spouses; and facilitation of social integration
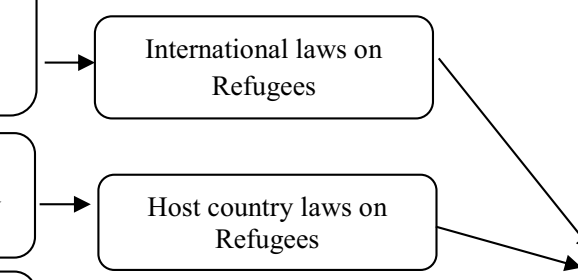

Substantial and Persistent Adversity 
Legal restrictions on the employability of Palestine refugees; difficulty in obtaining work permits in legal jobs; and inability to put into practice education linked with prohibited jobs

Entrepreneurship as a means to achieve a better personal economic situation, social situation, and to improve the family's socio-economic conditions.

Overcoming the refugee stigma and proving it to oneself and others through achieving financial and moral gains, self-improvement and independence, and giving back to society (Lebanese and Palestinian)

Supporting the Palestinian cause by achieving success and improving ability to give back; providing employment opportunities to other Palestinians; and empowering and supporting subgroups of the Palestinian society: women, children, addicts etc.

Lack of enforcement of laws on Palestinians; avoiding taxation; and prevailing laws greatly inhibiting Palestinians from registering their own business
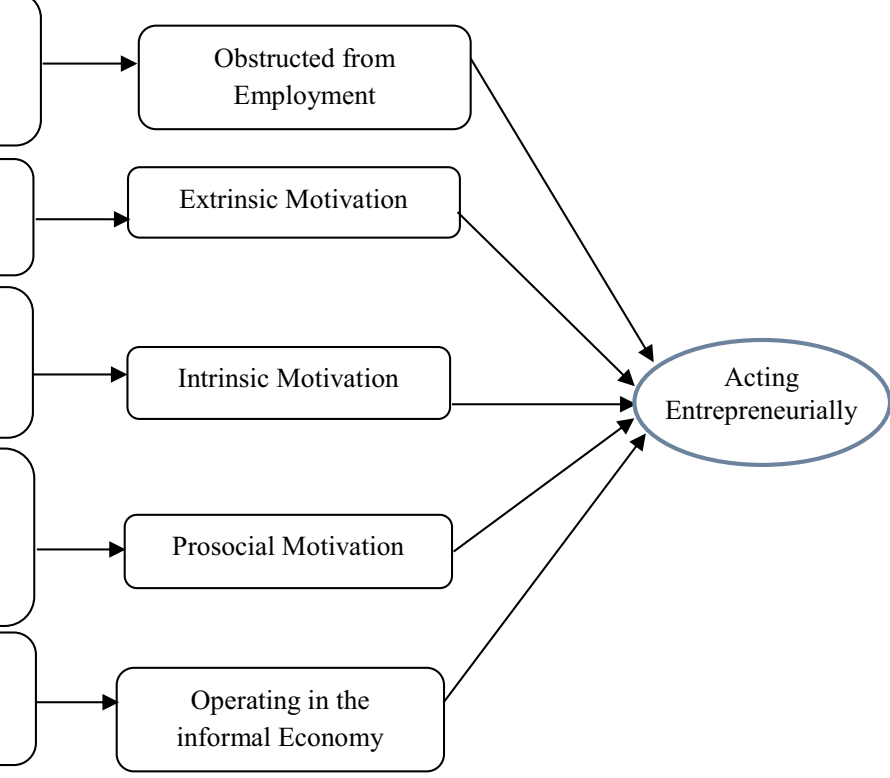

DIY attitude toward problem solving; self-teaching and selfimprovement to overcome problems; forward-looking attitude to mitigate against external risks; and Innovating or inventing new tools or solutions

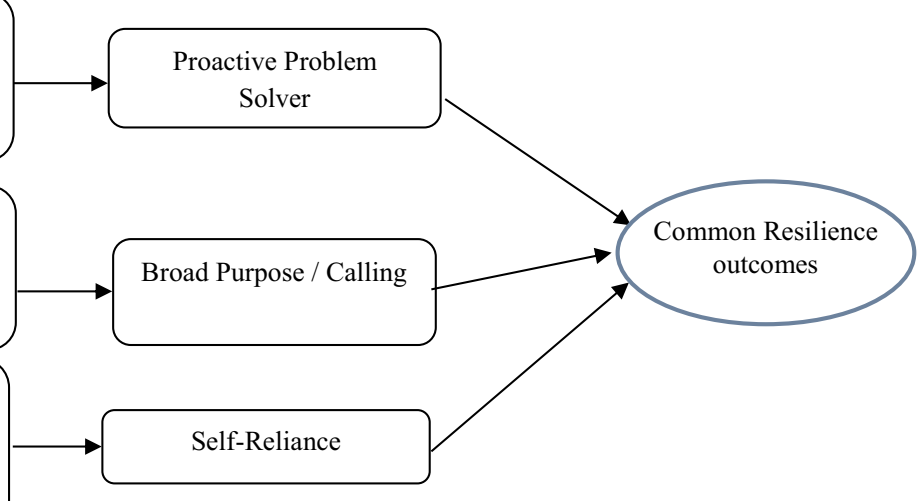

Drawing connections between own work and its benefits to the Palestinian cause; seeing the return to Palestine as a motivation to survive and succeed; and using own skills and experience to benefit the Palestinian society in Lebanon

Perception of abandonment by the international and local communities strengthens will to succeed; difficulty of access to financial and material resources enhances selfreliance; and taking full responsibility for the work, even in the case of partnershin with Lebanese

Overcoming difficulties with a positive and optimistic outlook; looking at problems as a positive challenge; and drawing optimism from the results of their work

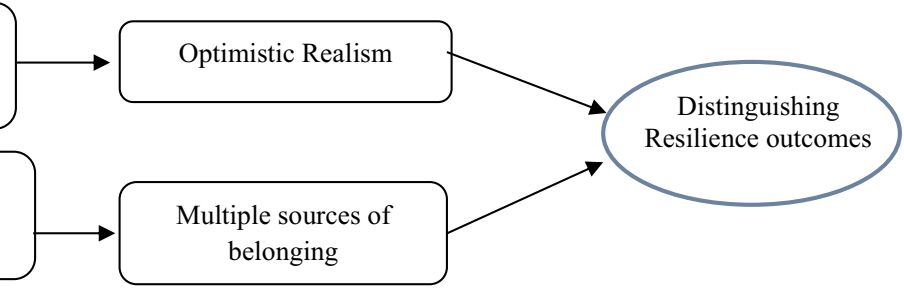

Identity overlapping between the Lebanese and Palestinian and Arab identities and expression of both Lebanese and Palestinian individual identities and collective identities

Fig. 1. (continued)

questions regarding the NGO's role in supporting or assisting Palestine refugees in Lebanon, the impact of the regulatory environment, entrepreneurship among Palestine refugees, and the extent of refugees' social integration.

Lastly, the semi-structure for the interviews with Lebanese citizens included questions related to the respondent's personal profile (e.g., How old are you; do you hold a Lebanese Passport?), general knowledge and opinions about Palestine refugees in Lebanon (e.g., Do you know roughly how many Palestinian refugees live in Lebanon; do you know how long they have been here?), knowledge and opinions about the regulatory environment affecting Palestine refugees (e.g., Do you know of any restrictions on the rights of Palestinians refugees? If yes, can you name some?), general knowledge and opinions about Palestine refugee entrepreneurs (e.g., Do you know of any restrictions on the ability of Palestinian refugees to start their own businesses? If yes, can you name some?), and opinions on the social integration of Palestine refugees in Lebanon (e.g., Do you think that something should be done to integrate the Palestinian refugees in Lebanon? Please explain why, or why not.). For accuracy, we audio-recorded all the interviews and video-recorded most of the entrepreneur interviews (23 out of 28 ), amounting to $3729 \mathrm{~min}$ of recording overall. We transcribed all the interviews in the 
respondents' original language (Arabic) and then translated the transcripts into English using a professional translator, which amounted to 745 pages of single-spaced text. We investigated both the transcriptions and translations for quality.

\subsubsection{Observation and archival sources}

In addition to recording the interviews, the interviewers reflected on their impressions of each interviewee, the context, and any thoughts or observations that were deemed relevant after the interviews. These field notes amounted to approximately 83 pages of single-spaced text. Although there was no archival data on the entrepreneurs (not surprising given the informal [illegal] nature of their businesses), we did collect archival data on the Palestine refugees in Lebanon from various official Lebanese and non-governmental sources, such as reports, brochures, statistics, press releases, and legal texts. These data amounted to 107 pages of singlespaced text.

\section{Data analysis}

We used a qualitative data-analysis software, NVIVO, to organize the large amount of data collected during the fieldwork. When coding the data, we simultaneously iterated between data collection and analysis (Strauss and Corbin, 1990; Suddaby, 2006). There were three stages of analysis: (1) open coding to generate first-order categories related to refugee entrepreneurs' resilience, (2) axial coding to generate second-order themes from the first-order categories, and (3) aggregating and abstracting from second-order themes into overarching dimensions.

Specifically, we began analyzing the data as they were gathered and translated, but we suspended concrete beliefs and theoretical associations (Charmaz, 2006; Locke, 2001). Although this process was largely inductive, we did focus on key issues related to resilience-that is, we were guided by our research question. We started by coding words or phrases that appeared to be important to the informants' resilience in terms of beliefs, actions, interactions, and conditions. Although the refugee entrepreneurs rarely used the word "resilience," it was clear that these individuals demonstrate aspects of positive functioning in the face of adversity. When possible, we used the informants' words to label like terms. Then, as we read and re-read the transcripts and our codes, we began to aggregate them into "similar codes," which represented the first-order categories. The first author was in charge of coding the first five interviews and generated an early list of first-order codes (Maanen, 1979). To achieve a common understanding of the code names and their meanings (Locke, 2001), the second and third authors used this preliminary code list to separately analyze an unprocessed interview. We discussed our divergences until we reached consensus on the meaning and naming of the codes. We then used this common list to make modifications to our semi-structure for subsequent interviews. For example, initial interviewees referred to people being "Lebanized" when discussing integration, so we asked more explicitly about this concept in later interviews. We repeated the formal data analysis three times to the point where we could no longer generate additional codes revealing patterns across the respondents. Specifically, we developed 40 first-order codes.

The first author then began looking for links between the first-order categories to cluster the categories into more abstract aggregate second-order themes (Corbin and Strauss, 1998) that were distinct from the theoretical themes of the first-order categories.

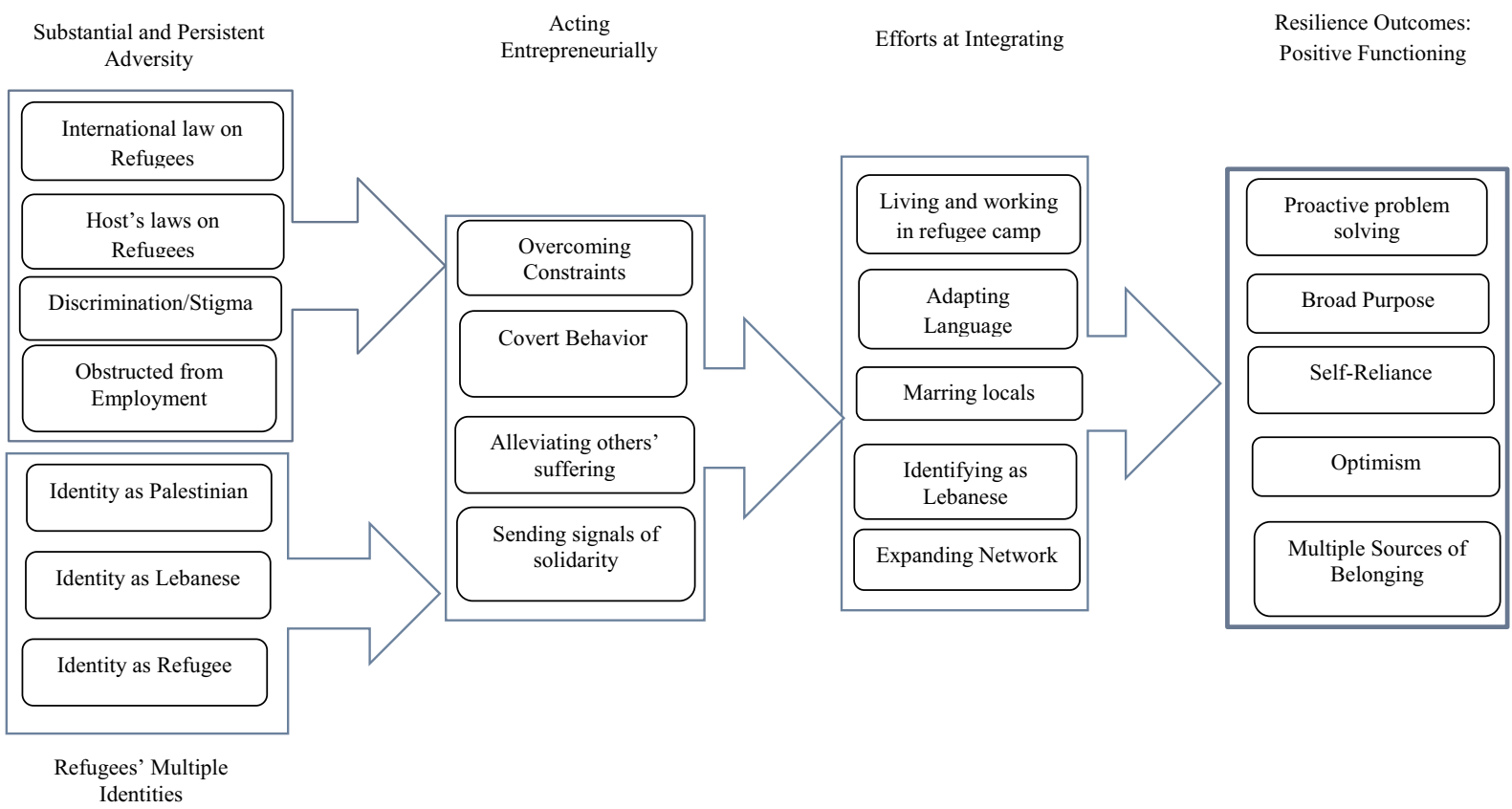

Fig. 2. Key Dynamics of Refugees' Entrepreneurial Actions to Enhance Integration and Resilience. 
For example, the first-order codes related to thoughts about the self in relation to "community," "entrepreneur," "family history," "multiple, identities" "nation," "politics," "religion," and "war" related to the second-order codes of "identity as Palestinian," "identity as refugee," and "identity as Lebanese." Therefore, relative to the first-order categories, the second-order themes were at a more abstract theoretical level, but when possible, we tried to maintain the informants' language in labeling these themes.

Finally, the first author organized the second-order themes into overarching dimensions as a basis for developing a grounded theoretical framework from the constructs and the relationships between the constructs that emerged from the data (Strauss and Corbin, 1990). The outcome was a refugee entrepreneurship model of resilience in the context of substantial and persistent adversity. For example, we organized the second-order codes of "identity as Palestinian," "identity as refugee," and "identity as Lebanese" into the overarching dimension of "refugee entrepreneurs' multiple identities." The second and third authors inspected the first-order categories, second-order themes, and overarching dimensions. The author team discussed the data structure and at times went back to the raw data to resolve minor issues to agree on the final data structure presented in Fig. 1. We also discussed our coding and findings with two of our original informants, who indicated that the first-order coding captured the scope of the topic and that the findings "made sense" to them given their knowledge of the situation "on the ground." This increased confidence in our coding.

\section{Findings}

In this study of entrepreneurial action as a vehicle for resilience in the context of substantial and persistent adversity, we explored the refugee entrepreneur context. In Fig. 1, we illustrate the emergent data structure. The boxes on the left indicate the first-order codes, the boxes in the middle indicate the second-order themes, and the circles on the right illustrate the overarching dimensions of the emergent data structure. This data structure offers a static perspective of what was a rather dynamic process. As a step toward developing an inductive model, we followed the sequence indicated in the data to offer an initial representation of the refugees' entrepreneurial action as a path to resilience outcomes-that is, to positive functioning (see Fig. 2). Fig. 1 illustrates the data structure as a bridge from the methods to the data, and Fig. 2 illustrates the data structure as a bridge from the data to an emergent theory (consistent with Nag et al., 2007). In Fig. 2, the first column represents the initial conditions of substantial and persistent adversity and the refugee entrepreneurs' multiple identities, the second column depicts entrepreneurial action (which largely operates in the informal economy), the third column represents refugee entrepreneurs' efforts at integrating or otherwise managing their multiple identities, and the fourth column captures the resilience to the substantial and persistent adversity of the refugee context. We now develop and report on these emergent findings before presenting our theoretical model.

\section{The refugee context of substantial and persistent (Objective) adversity}

\subsection{Legal constraints creating economic adversity and reinforcing social adversity}

The most prominent theme underlying the substantial and persistent adversity characterizing the refugee context is international law (or lack of its applicability) as it relates to the Palestinians in Lebanon. Palestine refugees have been in Lebanon for 70 years, and there is a special body within the United Nations (UNRWA) responsible for providing them relief assistance. However, Palestine refugees have a somewhat unique refugee status that leaves them in a state of legal limbo (Knudsen, 2009; Suleiman, 2006). Indeed, international and local laws have created a "no man's land" for Palestine refugees in Lebanon with no legal way for refugees to escape it (Al-Natour, 1997). This no man's land has created economic hardship for the Palestine refugees. They face economic hardship because there are only a few (low-paying) careers from which they can earn an income, which can lead to economic dependence on international aid. Rania M, a 45-year-old Lebanese national who lives and works in Beirut, indicated the refugees' economic adversity in the following:

They are denied work in 77 professions, although it is said that legally that number is lower. However, effectively, the barriers to being employed are very high. Essentially, they are prevented from employment in white collar positions. They are not allowed to open an NGO or association on their own. They must have a Lebanese partner. Our former Prime Minister, Rafiq Hariri, went even further and prevented the Palestinians from the right of inheritance. So, not only did they prevent them from owning property, but they also prevented them from passing on this property. The Americans, the Swiss, the Europeans, who we know nothing about and to whom we are not related, they are allowed to come to Lebanon, own property, and pass it on. But the Palestinians, who are from our land, who are our relatives, who share the same history, they are not allowed to own or inherit property. This [situation] is unacceptable.

Social adversity compounds these economic constraints (see Table 1). The Palestine refugees are looked down upon, institutionally discriminated against (Khalil, 2011; Halabi, 2004), and stigmatized by Lebanese citizens. For example, Atallah S., a freelance copywriter who lives in Beirut, described the social stigma these refugees face:

In some areas of a specific religious majority, people are not comfortable with the idea of Palestinians living in Lebanon, working and starting families, sharing a state, who have dreams and ambitions and are educated and cultured. One feels in some sections of society that racism exists against the Palestinian people due to the memories of the civil war; I don't think we can get into this now.

Overall, these economic and social constraints have created harsh conditions for the refugees we studied. Wafaa I., a social entrepreneur dedicated to Palestinian women's empowerment who lives in Sidon, summed up her views on the situation with the following: 
Table 1

Adversity and Identity.

Theme Representative quotations

Persistent adversity Laws on refugees

Discrimination/Stigma

Identity

Identifying as Palestinian

Identifying as refugee
"We would like to register our company and pay the taxes in order to win jobs with large companies and organizations. In short, the laws are the main reason why we, as entrepreneurs, cannot grow our business." (Maher S.)

"Yes, people refer to me as a contractor, but the main problem is that I cannot practice my field. I also do interior design, but I cannot be licensed. And if I take on any job, then someone else has to go get the papers signed at the syndicate in my place. The other challenge is that I don't have the right to own property. So, I have a business but I can't own a building or a plot of land" (Engineering subcontractor, Mohamad D.)

"We are banned from practicing most professions. There are truly very few jobs that we are allowed to practice." (Nisreen I.)

"The major obstacle today for the Palestinians refugees in Lebanon is their mobility, even beyond the confines of their camps. They still have a lot of trouble being mobile." (NGO: Nicolas Dawalibi, Injaz)

"We know that in Lebanon, they cannot open their own businesses; they cannot own property, they cannot find employment...they are prevented from all of this." (Amal, 51, Lebanese)

"As Lebanese, we are very afraid of something called nationalization (granting the Palestinians citizenship). Our politicians, if you like, have drilled this into our minds. We are afraid of nationalizing them. Don't you want me to be honest? If you grant citizenship to the refugees, whether Palestinians or others, there is a risk they will take our jobs and our rights." (Amal, 51, Lebanese) "Some do not buy our crafts, because we are Palestinian. As soon as these people see in an exhibition application that we are Palestinian they deny us from participating." (Ahmad I.)

"I hate racism and I wish people would stop humiliating us and treating us like refugees. We are human beings living in this country; humans made of flesh and blood like everyone else." (Ihab N.)

"So many of the young Palestinians I am in contact with who have answered an advertisement for a job who were almost accepted until they were asked about their ID or their nationality; they mentioned the dreaded word 'Palestinian' and, of course, the doors are immediately shut in their face." (NGO: Amb. Samir Khoury, CEP)

"No way I would buy from Palestinians. I wouldn't. I can't support Palestinian business before supporting Lebanese business." (Nareg Aslanian, 20, Lebanese)

"They take away jobs from the Lebanese, many are unemployed, and they put pressure on the infrastructure." (Khalil Haidar, 17, Lebanese)

"My nationality is Palestinian, and I am proud of it. Being Palestinian is an expression of many stories and histories. I am an ardent warrior for this cause." (Ahmad I.)

"I feel Palestinian until my last breath; I am a 50-year-old man and I still cry because of some of the things I hear. What is happening in Palestine affects me; I belong to Palestine, and at times I am unable to control my reactions." (Nasser K.)

"I say that I am 100\% Palestinian to preserve my cause. If I quantify how Palestinian I feel, then I would be losing my struggle for my cause. That's why I say that I am 100\% Palestinian. I divide my feeling, not my belonging, between Libya and Lebanon, but as they say, Palestine is like a sick child, we have to offer it all our love and care until it gets better. After all, it is a stolen country. That is why we say we are $100 \%$ Palestinian." (Amina A.)

"He's very proud of his heritage; he's very vocal of his heritage, and although he doesn't let his heritage define him, he's happy to define himself as Palestinian." (fiancée of filmmaker Ahmad M.)

He's Palestinian, of course, not just as somebody who identifies with his blue identity (refugee) card, it's not about that, but mentally he's Palestinian. Of course, he's Palestinian. That's non-negotiable. (Australian, customer of Maher S.)

"I am a Palestine refugee living in Lebanon. My name is on a large blue ID card, which is still handmade in the twenty first century. When I die they will find my name on this card, that's all." (Ihab N.)

"When my friends ask about my nationality, I tell them I'm Palestinian. When they ask me if I was born in Palestine, I tell them that it's not possible. I was born here, and I am still here. For this reason, I am a Palestine refugee living in Lebanon." (Ahmad M.)

"Yes, I do, because I have no country and no rights. Whatever rights I have are useless; so, naturally, I am a refugee." (Amina A.) "Yes, I do consider myself a refugee, a Palestine refugee. In my own understanding, the refugee is someone staying in one place temporarily; this bothers me." (Nasser K.)

"Because I am a refugee and can't be anything else. I have to hold on to this. As long as I am outside my land, my home country to which I belong, I will remain a refugee. I can't return whenever I want, but if one is Palestinian and living outside Palestine by their own will, then they are not a refugee." (Waad H.)

"Yes, of course, I feel Lebanese; I was born here and I have lived here my entire life." (Iman K.)

"Lebanon is also very beautiful, I was born here, but I love Palestine through the stories of my parents. In other words, I consider myself Lebanese...Lebanon is very beautiful. Who is able to hate Lebanon?" (Salah el Din A.)

"I am as protective of Lebanon as I am of Palestine. Lebanon touches us because we were raised here, and the idea of Palestine is one we have had since we were children: the land that was stolen from your grandparents. But I've grown up here, and my friends are here, and my entire life of 50 years has been spent here. Imagine what living in a country for 50 years makes you feel..!" (Salim S.)

"Identity is not only about belonging. It is also about your environment, the people with whom you grew up. If we can return to Palestine I will be the first to go back, but I will return here. Because a country is also the people you grew up with, not only stone and earth. Your homeland is where your memories are, where your people are. I would return to Palestine, but eventually I would come back to the people I love and who love me in return." (Marwan M.)

(continued on next page) 
Table 1 (continued)

\begin{tabular}{ll}
\hline Theme & Representative quotations \\
\hline Multiple identities & "Who am I? What is my identity? That's the point. I sometimes think about this matter. I always face pressures or big problems, but \\
in the end I'm not like people who have an ID card or a passport. Yes, this is my country, I was born here in Lebanon and I consider \\
it my country, but I can't determine if this is my country or not. Maybe if I were born in Palestine I would have been completely \\
different." (Ahmad M.) \\
"I am first a Palestinian, and then Lebanese. What I mean is that I am originally a Palestinian knowing that I never lived a moment \\
in Palestine, but I feel that it is a big part of me... We are Palestinians, we are Lebanese." (Bayan B.) \\
"It (Lebanon) is my second country, and my birthplace. Of course, I love it, with my soul not just my heart." (Ihab N.) \\
"Today there is no more confusion in how I introduce myself. Today I introduce myself as a Tripolitan (someone who is from the \\
northern city of Tripoli). I love this city, and of course I introduce myself as Palestinian. I feel a very strong connection and love to \\
the city of Tripoli and northern Lebanon...I belong to both places, the camp and Tripoli. I am first and foremost a human being, an \\
Arab, a Palestinian and Tripolitan" (Mourad A.)
\end{tabular}

The Lebanese people are racist, and if they don't practice their racism, then they hide it inside. For example, they say that foreigners took all the job opportunities, but employers used refugees and exploited them with low wages, and even if they were good workers, they are still not paid well. There are employers who say that they are against racism but hire Palestinians with a $\$ 400$ salary and Lebanese employees with higher wages. In Lebanon, whoever says that they are not racist are in fact racist in their hiring practices, and they don't give others their social rights.

A 57-year-old Lebanese national, who refused to reveal his name and lives in a neighborhood known to be unwelcoming to the Palestinians, expressed his views on the presence of Palestine refugees in Lebanon as follows:

They are a burden to Lebanon. They work illegally without permission from the (Lebanese) authorities. They earn social benefits, they receive support from UNRWA, and get a hundred other benefits. They beg in the streets and live in squalor in their camps. They are responsible for $75 \%$ of the thefts in the country. Three-quarters of the country's problems are caused by them. They work for illegal businesses. Most of our problems are caused by them. If not three-quarters then half of our problems are caused by them. They are responsible for security issues. Their presence in Lebanon does not have even a $1 \%$ benefit to Lebanon. There should be restrictions on their presence here. I don't know about their rights and duties in this country. In fact, I don't care. It's better if they sent them back to their country.

\subsection{Refugees developing and managing multiple identities}

While the refugee situation has created extreme economic and social adversity, it has also created an extreme context for multiple interacting identities (see Table 1). Although these individuals face many of the same challenges from having multiple identity challenges that most people face (e.g., those related to being a spouse and an employee (Wayne et al., 2017)), Palestine refugees face some additional identity-related issues.

First, these refugees identify as being Palestinian. At first, this might not be surprising for people classified as Palestine refugees, but interestingly, none but one of these individuals have ever seen Palestine. Most were born in refugee camps in Lebanon (i.e., those aged 30 or younger), and all face severe travel restrictions, including being banned from traveling out of Lebanon and into Palestine. Despite having never been to Palestine, these individuals still feel it is their home, not their birth home but their spiritual home. For example, Khaled Y., a freelance accountant who lives in a refugee camp near Tripoli, explained where he was born and why Palestine is such an important part of his identity: "I am Palestinian; it's only natural that I feel that I belong to Palestine. It is like asking a Lebanese or a Syrian the same question. Why should I be any different? Regardless of the fact that I cannot live in Palestine or how hard it is to live here."

Second, these individuals also identify with Lebanon (the country but not always the people). As mentioned, many of the Palestine refugees were born in Lebanon, or if they were not born in Lebanon, they have lived in Lebanon for the majority of their lives. Mohammad A., a furniture designer and carpenter who lives in a village in the Chouf district, described his identification with Lebanon the following way: "One's belonging is defined by where they were born and raised. Sometimes, the places that you belong to on paper do not mean a thing to you.. .. I consider myself an ordinary citizen of this country [Lebanon]." Although these individuals, when pressed, indicated that perhaps they are more Palestinian than Lebanese, they largely perceive their multiple identities as additive rather than a tradeoff. Indicative of this additive perspective of national identities, music entrepreneur Marwan M. explained how he was "equally from Lebanon and Palestine." Construction subcontractor Ihab N. added the Arab dimension when discussing his multiple identities:

My identity is Palestinian, my soul is Lebanese, and my nationality is Arab. I am like any other human being. I have no issues with race or nationality.. .. We are human beings living in this country; humans made of flesh and blood like everyone else.

Third, being a refugee is also part of their identity. For example, Bayan B., a freelance graphic designer and animator who lives in Beirut, noted the following: 
Yes, I am a refugee in every sense of the word; there are rights that we do not have. As a Palestinian and as a graphic designer, I know that we have a syndicate, but I cannot belong to this syndicate because I am Palestinian. If I have an accident or anything, I do not have national healthcare. I have to buy life and health insurance so that if something were to happen to me one day, insurance can cover my treatment costs.. .. I feel that I am a Palestine refugee in every sense of the word.

These individuals enact their refugee identity in recognition of how the Lebanese (and the world) sees them. However, our findings also indicate that while the refugee identity is mostly formed as the result of interactions with others, it also takes a slightly different form when the self conceives it. For example, Waad H., a translator, creative writer, and resident of Sidon, noted that a refugee camp is equivalent to a nation: "The camp is very important. It's like the capital of the refugee diaspora. It's home to a large number of Palestinians."

Finally, we found that for some refugee entrepreneurs, it is important to be able to switch rapidly from one identity to another and even to switch to some combination of identities. For example, music entrepreneur Marwan M., who lives in Beirut's southern suburbs, demonstrated identity switching when he told us the following: "I am an artist and. .. [when] someone asks the question (about my nationality), I can try to avoid the answer, but when they insist, I answer clearly." Freelance photographer Ghazi G. indicated how he was able to create and draw on some combination of his multiple identities: "My (Lebanese) accent is not artificial anymore. It has become natural for me. However, I sometimes try to use some Palestinian words when I communicate with other Palestinians." Indeed, for some, Lebanization represents a combination of multiple identities that has multiple levels that can be

Table 2

Adversity and identity.

Theme Represtative quotations

Acting entrepreneurially Obstructed from Employment

Extrinsic motivation

Intrinsic motivation

Prosocial motivation

Operating in the informal economy
"There are 76 professions Palestinians cannot practice. Palestinians are able to find jobs in these professions, but not legally. This prevents them from advancing in their jobs, and from joining syndicates." (Khaled Y.)

"Many of them never had the chance to be hired in their field. Others have no choice but to be self-employed ... because the Palestinians are denied access to so many professions." (Maher S.)

"In terms of what we said about the right to work and the professions they are allowed to practice in Lebanon are limited compared to the Lebanese. And this limitation goes especially on the well-paid jobs compared to the less-paid jobs: architects, doctors, engineers... Palestinians cannot practice these jobs. This leads as well to some kind of abuse and discrimination. Discrimination, of course, but also abuse." (NGO: Matteo Benatti, UNRWA)

"They have important human and social capital and can be beneficial to Lebanon. There are many highly educated Palestinians in universities, as well as engineers... Lebanon stands to benefit a lot from these people, but many of them cannot find jobs or join professional syndicates" (Rania Masri, 45, Lebanese)

"I feel that it is better to remain as an entrepreneur than to be an employee. This is because being employed doesn't help me (I will speak as a Palestinian), it doesn't bring any added value that would convince me to stay as an employee. For example, as a Palestinian employee, I cannot register in the National Social Security Fund. I cannot be promoted to higher positions in a company like any other Lebanese employee. This is a fact." (Bayan B.)

Interviewer: What are the benefits to you and to your family of having your own business? "First, the extra income, and communicating with people more, and success." (Iman K.)

"Despite the difficult situation we are in, there are many people who have worked as entrepreneurs and improved their own and their families' conditions. Many of those who prosper offer aid to those in need, like for students. And because of entrepreneurship, there are plenty of those who overcame the unemployment problem." (Khaled Y.)

"The future of my work relies on developing the market standards. I'm not only talking about self-development, but also the development of people around me. When I develop and train a crew, I also develop myself. I want to improve the standards of my trade." (Ahmad M.)

"By working on my own, I control my time, and I can delegate my work if I need to; it is more comfortable. Yes, it means more responsibility, but I am more comfortable this way." (Sara M.)

"I work hard because it is my own work, and I love my work. I feel internal satisfaction, and here is my benefit: it is moral and not financial." (Mariam S.)

"In my heart, I am supportive to Palestinians and the Palestinian cause to the largest extent. When someone asks me for anything for the cause or for Palestine, I do not hold back. I am willing to give blood, money, and soul, and this does not apply only to me, it applies to every (Palestinian) individual." (Marwan M.)

"An entrepreneur is a person who establishes their own business, through which they are able to benefit their society and themselves." (Mariam S.)

"Many of those who prosper offer aid to those in need, like for students. And because of entrepreneurship, there are plenty of those who overcame the unemployment problem." (Freelance accountant, Khaled Y.)

"I do not challenge the laws, I challenge reality. I spoke to you about the risks and my fears, and if you think about them, you won't be able to work. I can't stay home and do nothing. I want to think positively, and figure out ways to bypass the laws. Thankfully, the authorities also turn a blind eye to certain things." (Ihab N.)

"There are no laws to encourage people to undertake entrepreneurial projects, but we are good at challenging ourselves. Legally, there is nothing to encourage you; but in the camp, if you get an idea, you do it, regardless if the laws of the country allow it or not. Inside the camp, you can do whatever you want; there is no law to stop you, but there aren't any laws to protect you either." (Nader S.)

"Lebanon's economy is not $100 \%$ transparent. They let the Palestinians work illegally. They allow them to work, it's alright I guess. It's like for the Syrians (refugees) nowadays. The law says they cannot work, but they are working." (Mehyedin Shehab, 61, Lebanese) 
activated depending on the situation. We found that demands of the social context for some refugees lead them to switch between identities. This identity switching and combining appear to be triggered somewhat automatically by social cues to "fit in" as a survival mechanism.

Therefore, the overall conditions for the Palestine refugees in Lebanon include substantial and persistent adversity in the external environment and a complicated co-existence of multiple identities in the internal environment-that is, in the mind of the refugee entrepreneurs and in their inter-personal interactions with others (refugees and local Lebanese).

\section{Refugees acting entrepreneurially to overcome constraints}

Like for other individuals engaged in entrepreneurial action, some of the refugees indicated that they are motivated by economic rewards. For example, freelance graphic designer Bayan B. noted that he is motivated to engage in entrepreneurial action to generate income: "Sometimes if I need to finish a job for a customer in a competitive timeframe, then I earn good money for the job. In these cases, I work all days of the week, even on weekends." In contrast, Salah el Din A., who runs a t-shirt printing business and lives in a refugee camp near Tyr, appears to be more intrinsically motivated, stating that "The ambition inside me makes me special.. .. I would do the impossible to keep developing." However, for theory building, we focused on context-dependent findings because they provide the basis for new insights (see Table 2).

First, arising from the international and Lebanese laws discussed above, these refugees are not able to work legally (with a few minor exceptions). Indeed, it is difficult to circumvent these laws to obtain employment, but it is not impossible. For instance, to hire these "illegals," employing firms must put themselves in jeopardy, and firm owners must put forth considerable effort to "hide" wage payments to refugees. In contrast, it is easier for the refugees to circumvent Lebanese law themselves by becoming entrepreneurs. In this case, customers and suppliers of refugees' informal businesses can more easily plead ignorance about these businesses' legal status. Indeed, the data indicate that most customers and suppliers do not care who owns a business so long as the business provides them high value. For example, Mustafa A., a printing entrepreneur who lives in the Chouf district, explained to us that he is not afraid his suppliers will report his illegal business to the authorities: "My suppliers are only interested in commercial trade; they don't care about anything else." Therefore, obstructed from employment, the refugees we interviewed became entrepreneurs to earn an income (independent of charity).

Second, related to above, these entrepreneurs created businesses, which is against the law, so they operate in the informal economy. For example, Iman K., a home-based catering entrepreneur who lives in a Palestinian gathering in Tyr, explained the informal nature of her business: "I try working from home, so no one can find out what I am doing. I also select my customers and suppliers very carefully." Despite operating against the law, these entrepreneurs are not overly concerned about being caught because they believe authorities do not care a great deal about the infringement. Indeed, they believe both that the probability of being caught is low and that the punishment for being caught is low. Some Palestine refugees noted that if the punishment was more serious, they could use some Lebanese contacts to make "the problem go away" (i.e., a protector or a bribe). For example, freelance graphic designer Bayan B. referred to his lack of concern about being caught and penalized by police:

What could happen [if I get caught]? I could call someone. I always say to my friends in Lebanon that they should always have protection, like a politician. Every person should be able to count on a strong person in this country even if that person is a crook. Why? Because at some point we all might have a problem, and we need this backing.

Finally, we investigated this group of entrepreneurs because of the substantial and persistent adversity they face, yet the data provide evidence of their strong motivation to help other refugees. For example, social entrepreneur Wafaa I. noted the following:

We propose issues and projects that are different. We don't teach [Palestinian] women to become hairdressers because we want to break gender stereotypes. Instead, we propose projects that are linked with social realities-those that concern the female youths. We study their problems, and we carry out developmental projects. We don't give them ration boxes like the rest of the organizations.

In another example, Mohammad D., an engineering construction subcontractor who lives in Sidon, stated:

Like all youth, I had many goals, and I dream of having a role to play in rebuilding Palestine upon my return or in tidying up the camps that we currently live in. I dream of fixing narrow alleyways and tangled electrical wires and the sewage systems. The career that best suited this dream is civil engineering. Being a civil engineer enables me to serve my people and my country.

It appears that when facing adversity, individuals are near others who are suffering under these conditions, which stimulates behavior to help alleviate others' suffering. However, some entrepreneurs are motivated to stand out and be special-which may come as a result of financial success—-to serve as role models for other Palestine refugees. For example, Mona B. expressed how the Palestinians she knows in Lebanon view her cousin freelance designer Bayan B.: "The Palestinians in Lebanon, they love her [emphasis original]. She is what we call 'a winning model'; she is someone we look up to." However, this entrepreneurial motivation is likely the result of a sense of solidarity; solidarity among Palestine refugees has arisen from the misery of their shared circumstance and the Palestine cause (not solidarity in a shared solution to the adversity). Social entrepreneur Ahmad I. reflected on how this solidarity motivates behavior in the following way: "I work with a team that is young, talented, and experienced, that cares about their cause to the largest extent." 
Table 3

Integrating or isolating activities.

Theme Representative quotations

Integrating activities (Living and/or Working Outside a Refugee Camp)

Identifying as Lebanese

"I also feel Lebanese to a certain extent; I am one of the lucky ones who remained among a Lebanese surrounding yet at the same time maintained the Palestinian identity. Since all my network, friends and classmates from school and university, were all Lebanese, I had Lebanese concerns just like them." (Atallah S.)

"I am integrated in the Lebanese society. I considered myself a member of this society, and I consider that there is no difference between my culture and the culture of this society. I studied and worked here, and I was born here. I consider myself part and parcel of this society." (Maher S.)

"When you are integrated or assimilated within society, you become a part of that society. I feel that I am integrated to the greatest extent. We are all affected by what is happening in the Lebanese society; by the events, the economic situation; therefore, I consider that we are integrated in this society." (Mohamad A.)

Moving out of camps "As a life and income, I feel that living outside the camps is more comfortable. However, I always run into barriers because Palestinians are not allowed to own property, we have limited career options, and it is psychologically difficult because people see me as Palestinian. As a lifestyle I am comfortable living outside the camps, except when going from one place to another, you run into (Lebanese Army) checkpoints, and the phrase 'you are Palestinian' is disturbing to me." (Ahmad M.) "Living outside the camp is better, but you cannot escape the feeling of estrangement, people constantly make us feel like strangers in this country. Of course things changed after the arrival of Syrian refugees to Lebanon, people now treat them like strangers instead of us." (Amina A.)

"If they have a business, then they obviously have to make more of an effort to get out of the camp. So, naturally, this will happen". (NGO: Michelle Mouracade, Al Fanar)

Adapting language (Lebanizing) “To me, being 'Lebanized' means to adopt the Lebanese culture and interact with it. I consider myself 'Lebanized', but I hate using this word because my case is special." (Marwan M.)

"It would be an honor to be able to achieve that (Lebanization); it means the person is well integrated in the Lebanese society. Palestinians these days have connections with Lebanese people that are as strong as with other Palestinians; we cannot tell them apart sometimes anymore. Because of the intertwined relationships and people getting closer to each other. They dressing the same way, and speaking the same way." (Salah el Din A.)

"There are many Palestinians who speak fluent Lebanese and who would pass for Lebanese until they have to produce a piece of identity." (NGO: Amb. Samir Khoury, CEP)

Marriage $\quad$ "I was born here, and I grew up here. It is here that I got married and had children, and even married one of them. God willing, this is also where I will die." (Ihab N.)

"We got to a point where we are marrying Lebanese women in order to manage. If I've built a house, in whose name shall I put it? For example, when I think about my children. I'll give you an example, three quarters of Saida's construction was built by Palestinians married to Lebanese, and the properties are registered in the wives' names; or there would be a Lebanese partner." (Mustafa A.)

"There is a lot of mixing between the Palestinians and the Lebanese. A lot of intermarriage. The Palestinians suffered a lot. I know quite well the extent of their suffering because my father is married to a Palestinian." (Samer Dana, 55, Lebanese) "When they were asked for their ID's at the entrance, they were forbidden entry because they are 'foreigners', can you imagine? ... They did (enter eventually) after I put up a huge fight and made phone calls to powerful people.” (Ghazi G.) You have to try as much as you can to block the ways through which you could be prosecuted; and if you can't, you have to build a network of personal relationships; just like the Lebanese themselves do; and you have to also play along with the Lebanese society. (Wafaa I.)

"I had no trouble with the law thanks to my social relationships, as you must have wide social connections in order to get work." (Furniture designer, Mohamad A.)

"There are many stories of intermarriage, there are many stories of contacts, very friendly contacts especially at high levels with people who are entrepreneurs and have contacts with the Lebanese generally." (NGO: Amb. Samir Khoury, CEP)

Isolating activities (Living and Working Inside a Refugee Camp)

Singular Affiliation

"Life in the camp is composed of several layers, social, political, economic and cultural. The camp is our nation until we return to Palestine, and it is similar to any other city. ... We love the camp, through our culture, and with our ideas. Our opponents will always be afraid and terrified by the Palestinians, and we will keep it this way." (Ahmad, I).

"You cannot live inside the camp without talking about politics, the right of return, and the Palestinian cause. Regardless of our different opinions and points of view, it is impossible to find a kid that does not know the name of the village he/she came from in Palestine" (Khaled, Y).

"Palestinian terms, expressions, habits, and accents exist in their daily lives and, if you go to a Palestinian camp, you will notice that the streets are named after Palestinian villages or towns or areas. Even the shops have names like Jerusalem anything that might be related to Palestine" (Zafer, K).

Traditional Language

"Any child born in the camp speaks like the people of the camp" (Ahmad, I).

"... there is the camp's social life, which tempts anybody (Palestinian) to live in, and especially if they are in a Lebanese area. You always feel that the Palestinian likes to live in camps for their emotional and social aspects. The Palestinian dialect remains intact" (Nabil, $\mathrm{H}$ ).

Social bond "The only positive thing is the goodness of people and their humanity. People in the camp are sort of one big family" Ihab, N).

"I feel comfortable in any camp because I have worked in many of them, and I have many friends, but in the camp I live in, there's my family" (Khaled, Y).

"We visited each other a lot, which you don't often experience outside the camp. There are strong social connections; we celebrate together, and we mourn together. If someone is sick people collect money from each other so he gets treatment.

(continued on next page) 
Table 3 (continued)

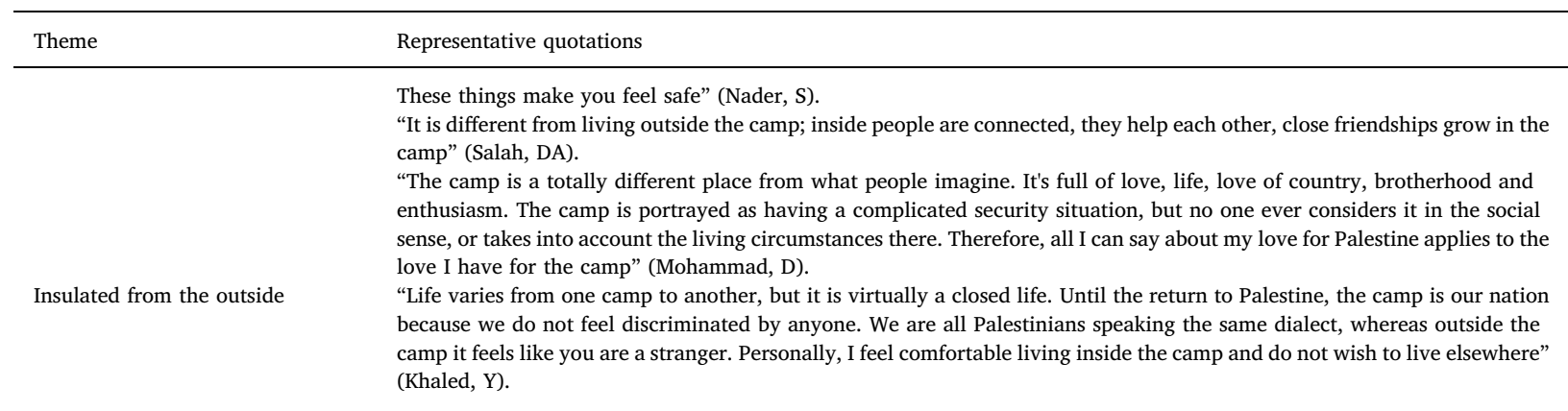

\section{Acting entrepreneurially facilitates refugees' integration efforts}

Many Palestine refugees live in one of 12 camps throughout Lebanon. Those living in the camps reported many beneficial features of camp life (see Table 3). First, living in a camp helps the refugees maintain a national identity separate from the rest of Lebanon. For example, Ahmad I. told us the following:

Life in the camp is composed of several layers: social, political, economic and cultural. The camp is our nation until we return to Palestine, and it is similar to any other city.. .. We love the camp through our culture and with our ideas. Our opponents will always be afraid and terrified by the Palestinians, and we will keep it this way.

Second, by living and working in the camps, these refugee entrepreneurs are able to keep their traditional language, which has other benefits for maintaining their Palestinian identity. For example, elaborating on the social benefits of living in a camp, Nabil H., a social entrepreneur who runs a sports and cultural organization in a Palestinian gathering in the Beqaa Valley, noted, "You always feel that the Palestinian likes to live in camps for their emotional and social aspects. The Palestinian dialect remains intact. You feel that the Palestinian's social and political life is more active within the camp."

Third, the camps help develop strong social bonds among refugees. Nader S., a social and cultural entrepreneur who was raised in a camp but lives in Tyr, spoke about the strong social relationships that exist among camp residents: "There are strong social connections; we celebrate together, and we mourn together. If someone is sick, people raise money, so he gets treatment. These things make you feel safe."

Finally, the camps appear to isolate the refugees from "outsiders." For example, freelance accountant Khaled Y. described how living in a camp is "virtually a closed life" that is free of discrimination, enables the refuges to use their traditional language, and provides great comfort.

However, other refugees reported some negatives of camp life, such as freelance copywriter Atallah S. in his description of the difficult socio-economic conditions: "A young man my age would live in anxiety if he fell in love, for example, not knowing where to live if he decided to get married. He can't build over his parent's already modest house. In short, life there is miserable." Others, like construction subcontractor Ihab N., who lives in a town south of Beirut, decried the lack of infrastructure and tough living conditions in camps: "There is no drinking water. The water that we get is salty and polluted. Mafias sell us clean water. Things got worse when the Syrian refugees arrived, and the camp became too crowded. No electricity, no infrastructure." Stills others, like freelance photographer Nasser K., spoke about the camps' negative effects on refugee children: "All these circumstances create deprivation, frustration, and abuse for little kids; this affects the foundation of their character. When they are older, it leaves an impact, a negative impact."

Of our sample, $68 \%$ live outside the camps (it is believed that $37 \%$ of Palestine refugees live outside the 12 official UNRWAadministered camps in Lebanon (Chaaban et al., 2016)). These individuals described living outside the camps as less strenuous and more comfortable than camp life. For example, social entrepreneur Zafer K., who lives and operates his cultural Lebanese-registered NGO in Sidon, noted that "For those who live outside the camp, they are removed from the difficulties of the camp, such as the constant state of siege and the deteriorating security."

Despite laws forbidding Palestine refugees from owning or leasing property, some individuals find ways to circumvent these property laws to live among Lebanese citizens (often involving a Lebanese relative signing the real estate contract), such as freelance photographer Nader S., who explained how he did it:

I am the legitimate owner of the flat, but it is not registered in my name. I want to make this point quite clear; I am not allowed to own property. In fact, when I got my first job after finishing my schooling, my fiancé, my now-wife, was also working for UNRWA.

We pooled our resources, and we bought a flat by monthly installments. But sadly, I cannot register it. My sister is Lebanese because she is married to a Lebanese, so we registered the flat in her name.

It appears that living outside the camps affords these individuals the opportunity to interact with local Lebanese and people of other nationalities (see Table 3). First, refugees living outside the camps reported how they were able to develop a stronger identity as 
Lebanese (in combination with their identity as Palestinian) than would have been possible if they had lived in a camp. For example, food caterer Iman K. prefers the less-restricted atmosphere outside the camps: "I am afraid of moving into the camp; the situation in the camp is very difficult. Life outside the camp is good. Dealing with people is easier than in the camp; it is less conservative. The camp is a closed space. People who live there do not leave the camp very often." Indeed, social entrepreneur Nabil H. emphasized the higher mobility that exists outside the camps: "Once you live outside of the camp, movement becomes a little easier. It's because you're living in a Lebanese environment and society, and so everything is open. Going out and returning is different than being under siege in camp." Living outside the refugee camps helps the refugee entrepreneurs integrate with (non-refugee) locals in their businesses and in living their lives.

Although most Palestine refugees identify with the country of Lebanon, there is greater heterogeneity in the extent to which they identify with the Lebanese people (even among those living and/or working outside the refugee camps). Those with low integration largely resent the Lebanese people due to the discrimination and stigma applied to Palestine refugees. Palestine refugees who are more integrated into Lebanese society tend to develop a more nuanced (or fine-grained) understanding of the people in Lebanon. For

Table 4

Resilience outcomes.

Theme Representative quotations

Shared Resilience

Proactive problem solving

Broad purpose/Calling (for Palestine)

Self-reliance

Resilience from integrating activities Optimistic realism

Multiple sources of belonging
"Perhaps because of our hardship, Palestinians are forced to innovate. If we were more privileged, then we would not search for new ideas." (Mariam S.)

"I always deal with problems by facing them head on, and I believe that every problem has a solution, and I do not abandon my problems because I am perseverant and stubborn and a bit rebellious." (Maher S.)

"Maybe the situation, the conditions that they live in push them to think well to come up with good ideas. To struggle to succeed. They don't have any other option. So, if they get some funds, they know that this is perhaps the first and last time that they get funds, so they have to succeed. They don't have any other option. It's like commitment that they will succeed and they will survive. The situation that they live in pushes them to do miracles." (NGO: Nazih Yaacoub, UNICEF)

"I have plenty of ideas, objectives, and the ambition that I want to achieve, in the hope of returning to Palestine." (Social entrepreneur, Mariam S.)

"My life revolves around anything that is connected to Palestine. I always say that I want to, and I try to, be a part of any movement connected to Palestine. I consider Palestine to be the most important thing in my life." (Freelance designer and producer, Maher S.)

"Yes, it does. My daily life, my education, my work, all are never far from Palestine, or my duty and belonging to Palestine. My speeches are also about Palestine; in every detail of my life even in love and romance. This issue for us is eternal, a constant feeling, we will die as we were born." (Social entrepreneur, Zafer K.)

"To me the Palestinian cause is paramount, a priority. I think one should pursue his ambitions and dreams regardless of the difficulties." (Freelance copywriter, Atallah S.)

"The project I'm doing is a small business supported by an NGO. I will build myself from here without anyone's help. I am also a topographer by training, and I will also try to find job opportunities to support my business." (Salah el Din A.)

"I run all aspects of the business; I am responsible for everything, but because of the Lebanese laws, a Palestinian is allowed to own only $49 \%$ of a business and the Lebanese partner should have $51 \%$. This is the situation we live in, but I carry the entire workload." (Wissam K.)

"I am essentially responsible for myself, even when I started to live on my own, see if I want to go to someone who will that be? I have my family, but other than my family, I have no one. Every day I work hard and with a strong motivation so that I don't lose what I have gained. I am responsible for myself, and I have no one to protect me." (Bayan B.)

"You feel optimism when seeing the people around you work as hard as they do, what you offer them, instead of submitting to the reality and sit around waiting for the day we return to Palestine." (Social entrepreneur, Ahmad I.) "What I mean by optimistic is that if doors close, they will reopen; and your life and professional experience and your degrees and your personality and your identity will open doors for you. As long as you have the keys and the skills and the strength, you will always find an opportunity to exploit." (Social entrepreneur, Wafaa I.)

"Regarding the challenges he faces at work, he doesn't consider anything to be unachievable. He believes that every problem has a solution." (wife of Mustafa A.)

"You know, sometimes I ask myself the question: what am I? Am a Palestinian, or am I Lebanese? However, it is certain that the Palestinian part is engraved in my heart. We were brought up this way. That we are Palestinians, and that we must return to our lands, and that we own the keys to our homes, and that we have the papers that prove that we own land and that we are from Palestine. However, at other times, I feel like I am not from any country." (Bayan B.)

It varies; those living in the camps might see me as "Lebanized". However, emotionally, I hold both nationalities. (Ghazi G.)

"I feel a belonging to Lebanon in many situations, especially while traveling abroad. I introduce myself as Palestinian from Lebanon, and it saddens me to hear people say bad things about Lebanon. I feel I am from this country, naturally. If I weren't in this country, I would not have been influenced by it, I would not have been influenced by the features of its people and its traditions, and customs... We are a part of this country, we cannot separate ourselves from it and say that we are only Palestinian. We interact with each other, whether we want it or not, or whether they want it or not." (Mourad A.) 
example, catering entrepreneur Imam K. noted, "My relationship with the Lebanese is good, but I feel that there is something that separates them from us; it is a strange feeling." Similarly, acknowledging that some Lebanese people are good and some are bad, Ghazi G., a freelance photographer, noted the following:

My relationship with the Lebanese is excellent. As I said, it's my second country. I was born here, and I am proud of Lebanon. I am thankful that I am Palestinian born in Lebanon and not somewhere else. Lebanon is a great country. I am good with people. Some don't accept you because you're Palestinian. They think you came from another planet. Others behave differently; they truly care about Palestine and the cause.

Second, Palestine refugees living outside the camps often adapt their language to sound like a Lebanese local to promote their businesses. We found that individuals referred to this adaptation as being "Lebanized." Some regard the word with positive connotations of integration (mostly those who live outside the camps or have Lebanese parents or relatives), whereas others feel the term has negative connotations (mostly those who live in the refugee camps or work primarily in the camps). For example, filmmaker Ahmad M., who lives in Sidon, described the term "Lebanized" with disdain:

Perhaps it doesn't mean as much to me as to others. Maybe some would say that a person has become Lebanized and lost his identity. But for me, a Lebanized person is someone who fakes being Lebanese to get by in life. When a person is not true to himself, he begins to lose a lot of things. He is a fake.

Therefore, when Lebanization occurs somewhat naturally, it captures the evolution of integration, but when it is inauthentic (i.e., "put on"), it represents an impression-management strategy by Palestine refugees to overcome the social stigma applied to them by the Lebanese.

Third, Palestine refugees' integration outside the camps is reflected and facilitated by their marrying local Lebanese. Namely, marrying a local somewhat helps with integration (see Haddad and Jamali, 2003) and with business development. For example, Mariam S., a social entrepreneur empowering Palestinian women through a Lebanese-registered NGO, explained the following:

We have been here 70 years, and intermarriage between the Palestinians and the Lebanese plays a major role [in society]. I sense this during international conferences when Palestinians and Lebanese meet. We behave as if we are from the same country and are related.

However, some adversity remains for those who marry a local, such as furniture designer Mohamad A., who explained, "Even if I were to register the business in my wife's name, then I would be an employee. By law, the company would then have to employ two Lebanese employees, and I wouldn't be able to work in my own company!"

Finally, running a business can help the refugee entrepreneurs integrate with Lebanese locals and generate relationships with a broad array of people. In the refugees' social networks, this broad array of relationships is important. For example, furniture designer Mohammad A. made an effort to integrate, finding that his expanded network helped in his business: "The nature of my work relies on building connections with everyone in Lebanese society, with people from all political parties and religious sects without exception."

\section{Refugee entrepreneurs' resilience outcomes}

The data indicate dimensions of positive functioning in the face of substantial and persistent adversity-namely, resilience outcomes (see Table 4). We found the refugee entrepreneurs share some resilience outcomes but differ on others-the refugee entrepreneurs living and working in the camps generate some but not all of the resilience outcomes generated by those living and/or working outside the camps. We start with the shared resilience outcomes for refugee entrepreneurs (regardless of their interactions outside the refugee camps).

First, the data indicate that all the refugee entrepreneurs are proactive problem solvers. For example, Mustafa A., who runs an advertising and printing press business, displayed proactive problem solving when he told us, "In this country, you need to be prepared; you must have a generator, and you need to be equipped. These precautions pay off. So, you need to know how to commit to your business." Although proactive problem solving may facilitate an individual's positive functioning, it is also an indication of positive functioning (e.g., Folkman, 2013; Fredrickson and Joiner, 2002).

Second, all the refugee entrepreneurs think about the past and project into the future and are ultimately driven by a broader purpose than the self. For example, social entrepreneur Ahmad I. noted, "I am a person who grew up belonging to a great cause. I have a grand dream: to return to Palestine. I think of my work as a bridge toward the right of return. All I do is a part of a cause I believe in." These individuals draw on a historical perspective to generate and anchor a broader purpose in their lives. Achieving what they believe are moral gains reflects this broader purpose-namely, the "appropriate" treatment of Palestine refugees.

Finally, all the refugee entrepreneurs frequently referred to a lack of help; however, these expressions were not attributions of blame but were stated as simple facts. The data indicate that the refugees use this "lack of help" as a motivation to be proactive in looking after themselves and other community members (because they believe that no one else will). Indeed, the refugees often display strong self-reliance. For example, filmmaker Ahmad M. indicated self-reliance when he highlighted the following:

I guess every person is responsible for himself in Lebanon. I don't believe anyone is responsible for the Palestinians in Lebanon. Palestinians are only considered people who were born here.. .. So, when I think of myself as a Palestinian, and I think about working, I must forget all the obstacles I am faced with, and I must consider that no one will help me. This is why I must be responsible for myself in all situations, whether positive or negative. 
Although the refugee entrepreneurs share the above resilience outcomes, there are two additional resilience outcomes shared by those who live and/or work outside the camps (see Table 4). First, despite the objective and persistent adversity, the refugee entrepreneurs living and/or working outside the refugee camps tend to have an optimistic outlook. For example, Sara M., a catering entrepreneur specializing in diabetic-friendly sweets, noted, "Yes, of course I am optimistic because determination leads to success, God willing. I will keep going as long as I can, and working will help us achieve our goals. I will pursue this till my last breath."

However, these entrepreneurs' optimism also reflects a level of realism. That is, they are as optimistic as their precarious situation allows them to be. Therefore, this is optimism of the future tempered somewhat by a sense of realism that emerges from past disappointments and experiences. As an example of this realistic optimism, Nicolas D., an NGO project manager of an entrepreneurship-development program for underprivileged youth, noted the following about the young Palestine refugee entrepreneurs who participate in the program: "There are some who are still very skeptical about a lot of things but still manage to push forward. They still doubt it, but you know that deep inside, they are willing to take that leap and see where it might lead them." Similarly, freelance copywriter Atallah S. explained the role optimism played when he started his venture:

It is necessary to take risks, to get rid of the nagging feeling that keeps telling you, "What if? What if I started my own business, what would happen?" When I started, I felt a psychological relief frankly. I had to overcome difficulties for sure. However, as I told you, I am optimistic; you never know how far you can go if you don't start.

Second, the findings indicate that while the multiple identities of the refugee entrepreneurs living and/or working outside the refugee camps create some identity-management challenges, they also reflect multiple sources of belonging. The refugee entrepreneurs feel a sense of belonging to the land of Palestine (including to other Palestinians in Lebanon and to Palestinians around the world [even though they realize that they are unlikely to meet such people]) and to Lebanon (and to a greater or lesser extent to the Lebanese people). In contrast, the refugee entrepreneurs living and working in the camps identify with the former but rarely with the latter. Above, we have already described the refugees' identification with Palestine and Lebanon.

\section{Reciprocal relationships}

There are three primary recursive relationships in this model. First, resilience outcomes enhance the refugees' entrepreneurial actions. For example, Amina's husband told us of how her positive functioning (in the face of adversity) facilitated her entrepreneurial action:

Amina is very dynamic; she loves her work and does it with great care. She knows how to overcome the difficulties when resources are lacking. When she launched her business, she had very small starting capital... . She started with only US $\$ 200$, and she bought spools of thread, and she recruited women to embroider for free. She then held an exhibition, and she sold the robes, and after paying the women, she used the profits to buy additional equipment and supplies. She used every opportunity to spend her savings on improving the business. Within six years, she managed to become very well known in our community. (Palestinian husband of Amina A.)

Second, resilience outcomes facilitate the refugee entrepreneurs' integration activities. For example, one Lebanese customer was so impressed with Wissam K.'s personal perseverance that he partnered with him:

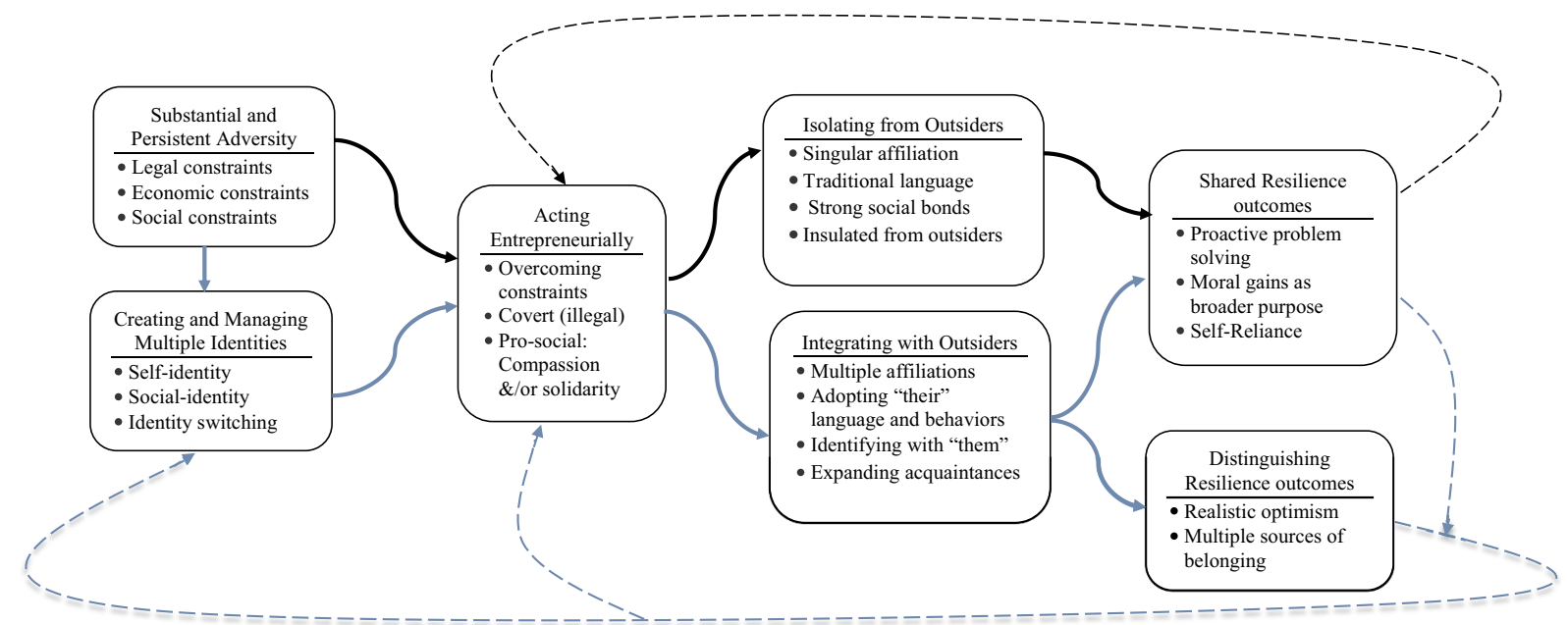

Fig. 3. A Refugee Entrepreneurship Model of Resilience to Substantial and Persistent Resilience. 
Wissam used to be my employee, and then he decided he wanted to start his own business. So, I decided to partner with him because this is a business I am familiar with. I became his partner, and at the same time, I became his customer.. .. He is a very hardworking and perseverant man... .. He is technically very good, and he masters his work.

The third recursive relationship highlights how integration efforts can influence the nature of the refugee entrepreneurs' multiple identities and the way that they manage those identities, which may enable them to avoid some of the adversity embedded in their context. For example, the husband of Amina A. described the impact her business-related interactions have had on her social, psychological, and physical development:

Our social situation is very good. Amina has developed many relationships and is able to make introductions. The benefits of her work are not only financial, and there is another side to it: especially as a woman, she feels that work gives her a purpose in life. She is here, and she is working. She is not wasting her time around coffee and waterpipes; she is filling her time in a good way, and this is important. Her work also helps her psychological and physical well-being. There are material and moral benefits to her work. That's for sure.

Notable recursive relationships are also not present. Namely, the model does not indicate any recursive relationships for the source of adversity; hence, its persistent nature. In this model, entrepreneurial action and the dynamics of identity help the refugee entrepreneurs' resilience under high adversity without directly impacting the objective level of the adversity. Therefore, in this instance, entrepreneurial action is not a basis for changing the status quo; rather, it enables the refugee entrepreneurs to proactively construct personal shields to deflect some adversity to generate resilience outcomes.

\section{A grounded model of entrepreneurial action and resilience to substantial and persistent adversity}

Resilience involves positive functioning in the face of adversity. Our data on Palestine refugees in Lebanon indicate a form of adversity that is both substantial and persistent, with entrepreneurial action and multiple identities closely tied to resilience to this adversity. In this section, we build on our analysis to offer a grounded model that highlights the most important progressive and recursive relationships underlying the dynamism evident in the data. The model not only captures the dynamism of entrepreneurial action and resilience for Palestine refugees in Lebanon but also represents a model more generally applicable to other refugee situations and other situations of substantial and persistent adversity.

We offer our grounded model in Fig. 3. In the context of substantial and persistent adversity, individuals face legal, economic, and social constraints that perpetuate the adversity. Individuals also have multiple identities-created by the self and through interactions with others-as the result of living and interacting in this adverse environment. The substantial and persistent adversity signals that a passive response is unlikely to help; rather, the nature of the adversity requires entrepreneurial action as a means to circumvent the constraints of the status quo. Indeed, with such substantial and persistent adversity, entrepreneurial action needs to be covert to overcome the constraints and avoid the sanctions that go with breeching such constraints. Furthermore, although the adversity drives entrepreneurs toward personal gain, helping others (i.e., by alleviating suffering and indicating solidarity) also motivates these individuals to engage in entrepreneurial action. The resilience outcomes of this entrepreneurial action include proactive problem solving, moral gains as a broader purpose in life, and self-reliance.

Acting entrepreneurially also has an indirect path to resilience outcomes through integration activities. More specifically, entrepreneurial action facilitates interactions with those outside the adverse context, which provides a basis for entrepreneurs to adopt new behaviors and expand their networks through the addition of a broader array of relationships. In turn, these integration efforts facilitate resilience in the face of substantial and persistent adversity that includes the previously mentioned resilience outcomes_proactive problem solving, moral gains as a broader purpose in life, and self-reliance-as well as the resilience outcomes of realistic optimism and multiple sources of belonging.

There are three primary recursive relationships in this model: (1) resilience outcomes enhance entrepreneurial action, (2) resilience outcomes facilitate integration activities, and (3) integration efforts influence the nature and management of multiple identities.

\section{Discussion}

Our study reveals the importance of the direct, indirect, and recursive relationships among actions (i.e., entrepreneurial action and integration activities), multiple identities, and resilience outcomes under conditions of substantial and persistent adversity. Living under such adversity, the refugees we studied act entrepreneurially-motivated both by self-interest and the desire to help others-which directly and indirectly influences their resilience outcomes but not the underlying source of their adversity. Some of these refugees work and/or live outside the refugee camps, which triggers integration activities and the management of multiple identities. Although this context is extreme it is important for theory building and of practical relevance to many entrepreneurs who are refugees or operating under highly containing environments, thereby meeting calls for more contextualization of entrepreneurship research (Welter, 2011; Welter et al., 2017). The findings of this study have important implications for how we (1) account for the motivation of entrepreneurial action in highly constrained environments; (2) investigate the antecedents and 
consequences of entrepreneurs' resilience outcomes in the face of substantial and persistent adversity; and (3) think about the nature, management, and integration of multiple identities by refugees running a business. Overall, this study indicates that entrepreneurial action is a means for achieving resilience outcomes without having to address the underlying source(s) of adversity. These findings provide new insights, to which we now turn.

First, resilience has been explored in terms of individuals' endowments of resources before an adverse event (e.g., Bonanno et al., 2010; Hobfoll, 1989; Sutcliffe and Vogus, 2003), vulnerability to and preparation for an adverse event (Roberts, 1990; Drabek and McEntire, 2003; Vogus and Sutcliffe, 2007), and responses to sustain and maintain functioning until the consequences of an adverse event subside (Dewald and Bowen, 2010; Lengnick-Hall and Beck, 2005; Shepherd and Williams, 2014). However, substantial adversity is not always a specific event within a limited time period (consistent with adversity created by a disaster) but can persist over an extended period. Indeed, adversity can occur over such an extended period that an individual does not experience a pre-adversity period, and the foundations of the adversity can be so strong that the objective conditions are unlikely to change in the foreseeable future. The resilience literature has largely ignored this context of substantial and persistent adversity-an important contextualization of recent research on the role of entrepreneurial action under adversity (Shepherd and Williams, 2014; Powell and Baker, 2014, 2017; Williams and Shepherd, 2016a).

The under-exploration of resilience to substantial and persistent adversity is surprising given the prevalence of this form of adversity. Indeed, when we think of people in the world facing hardship today, we generally recall some instance of persistent adversity operating over generations-for example, the substantial and persistent adversity faced by many farmers (i.e., McElwee, 2006; Korsgaard et al., 2015; Korsgaard et al., 2015) and other entrepreneurs in depleted locations (Berglund et al., 2016; Korsgaard et al., 2016). There is a substantial stream of research on the nature and causes of persistent adversity (Bradley and Corwyn, 2002; Matthews and Gallo, 2011; Sachs, 2008) and both its consequences (e.g., Bradley and Corwyn, 2002; Diez Roux and Mair, 2010) and potential solutions (e.g., Anderson and Markides, 2007; Halme et al., 2012; Prahalad, 2006). However, surprisingly, the findings from this substantial stream of research rarely include resilience outcomes for the individual facing the adversity. In this study, we demonstrate the importance of understanding the role of resilience outcomes in contexts with substantial adversity over an extended period and show that entrepreneurial action is central to individuals' ability to deal with this form of adversity.

Second, resilience has been explored as a process or as an outcome (Williams et al., 2017). In the current study, our findings indicate that resilience outcomes are both a consequence and an antecedent (i.e., a reciprocal relationship) of entrepreneurial action. Most revelatory is the finding that resilience outcomes facilitate the entrepreneurial action that generates resilience outcomes. Specifically, we found the dimensions of resilience outcomes to include realistic optimism, proactive problem solving, moral gains as a broader purpose in life, self-reliance, and multiple sources of belonging. Given that resilience outcomes involve maintaining positive functioning in the face of adversity, it comes as no real surprise that these dimensions of positive functioning closely align with other scholars' dimensions of well-being (Ryff, 1989; Ryff and Keyes, 1995). What is interesting is that these outcomes are also important inputs to the refugee entrepreneurship process. That is, there is mutual causation between entrepreneurial action and resilience outcomes that serves as the basis for a resilience spiral. More theorizing and empirical research is needed to understand (1) how the different dimensions of resilience enhance the dimensions of entrepreneurial action; (2) what starts, perpetuates, and stops the resilience spiral; and (3) whether the resilience spiral can generate personal growth (i.e., an increase in personal functioning) and other constructs of positive psychology (e.g., flourishing, vitality, and psychological capital) (Dutton et al., 2008).

Third, there has been substantial research on how individuals' social capital (Aldrich, 2012; Aldrich and Meyer, 2015) and networks (Anderies et al., 2006; Janssen et al., 2006) are important capabilities for fostering resilience. The capability argument is consistent with the notion of adversity as an event (Bonanno et al., 2010; Hobfoll, 1989; Sutcliffe and Vogus, 2003; including an event that has a long incubation period [Roberts, 1990; Weick et al., 1999; Wildavsky, 1988]) such that an actor's endowments facilitate resilience outcomes. In this study, many individuals were born into adversity, so there is no pre-adversity period or pre-adversity capabilities to draw on. In this substantial and persistent adversity, individuals must create and develop capabilities for resilience as they experience the adversity. The findings of our study reveal the following about the capability argument: (1) the "social" capability for resilience is not an endowment but is created through activities that build a social basis for resilience outcomes, (2) social integration activities are initiated and facilitated by engaging in entrepreneurial action with non-similar others, and (3) resilience outcomes help individuals both engage in integration activities and build the social capability of resilience. Therefore, in the context of substantial and persistent adversity, individuals need to act to build (rather than simply deploy) their social capability of resilience.

Fourth, there has been an important stream of research on the role of identity in recovery from adversity (Maitlis, 2009; Powell and Baker, 2014; Shepherd and Williams, 2018). We complement this stream of research by extending our understanding of the role of identity in determining resilience outcomes. Our research context is certainly extreme in terms of the strength and diversity of individuals' multiple identities. The nature of these multiple identities is influenced directly by the substantial and persistent adversity; that is, the adversity shapes the self-categorizations and social interactions that make up individuals' multiple identities. Although the adversity may not change, individuals' actions (i.e., entrepreneurial and integration) and resilience outcomes provide a basis for changing the nature (i.e., mix) of their multiple identities. Indeed, identity is critical in generating entrepreneurial action (Cardon et al., 2009; Murnieks et al., 2014), and entrepreneurial action can help individuals build authentic identities (Haynie and Shepherd, 2011; Powell and Baker, 2014). We enrich this literature through the insight that in this persistently adverse context, the relationship between entrepreneurial action and identity is not one way and static but bidirectional and dynamic. More research is needed on how an individual's configuration of multiple identities evolves and how this configuration influences the evolution of 
entrepreneurial action and social interactions. This evolution may be so slow as to require a longitudinal study across generations.

Finally, the current study highlights how adversity causes others' suffering, which triggers a prosocial motivation for entrepreneurial action (consistent with the notion of compassion venturing [Shepherd and Williams, 2014; Williams and Shepherd, 2016b]). However, over and above the prosocial motivation of compassion, we also found a prosocial motivation to promote solidarity: "You are not alone; we are in this together as part of a broader purpose in life." Although we did not focus on others' suffering in this study, future research can explore the influence of entrepreneurial action on both individuals' resilience outcomes and their desire to help others (i.e., alleviating suffering or generating solidarity) and on the inter-relationship between the two.

\section{Conclusion}

Research on individuals in adverse situations offers accounts about the importance of resource endowments and pre-adversity organizing prior to adverse events. In doing so, these studies emphasize the overwhelming events encountered and the cognitions, emotions, and behaviors needed to maintain positive functioning in the face of adversity. By highlighting the importance of understanding resilience over an extended period and the persistent adversity of refugees born in refugee camps, we complement these studies with an account of substantial and persistent adversity and elaborate upon a model wherein identity plays a central role in entrepreneurial action for resilience. This model emphasizes the role of entrepreneurial action in generating resilience outcomes in the face of adversity. We believe our emergent theorizing regarding the direct, indirect, and recursive relationships among entrepreneurial action and integration activities, multiple identities, and resilience outcomes makes important contributions to the entrepreneurship literature. Moreover, because we found that refugee entrepreneurs living outside refugee camps achieve resilience outcomes not accessible to those living inside these camps, our findings offer new insights into the use and management of multiple identities to achieve positive personal functioning in the face of adversity. We hope other researchers and subsequent studies will find our model useful as they augment thinking of this important line of study. Unfortunately, substantial and persistent adversity is prevalent, and the number of refugees is large, thus creating important future research topics for scholars.

We recognize that all studies have limitations, including this one. We highlight these limitations as sources of opportunities for future theorizing and empirical work. First, we chose this sample because it was extreme and therefore advantageous for theory building. The flipside to the same coin is the issue of generalizability. That is, although the purpose of this study is theory building, there are likely questions about generalizing the study to other contexts. Even if the findings are not generalizable beyond the Palestine refugees in Lebanon or beyond refugees, these both represent substantial and important populations (i.e., 175,000 and 23.5 million people, respectively) (LPDC, 2018). However, we believe that as the refugee entrepreneurship model emerged, we were able to offer a more generalized framework of entrepreneurial action and resilience in the face of substantial and persistent adversity. We hope that future research explores entrepreneurial action in other refugee contexts as well as resilience antecedents and outcomes in non-refugee contexts in which adversity is substantial and persistent.

Indeed, time is another issue for further consideration. Although we collected data over a 15-month period, we did not conduct a longitudinal study because we focused on a context of persistent adversity; we did not expect to find considerable change in the context over the short to moderate run. However, future research has the opportunity to revisit individuals facing this form of adversity to explore the evolution of their entrepreneurial action, integration activities, multiple identities, and resilience outcomes. For example, what happens to a refugee entrepreneur who changes from living and working inside a refugee camp to living and working outside a refugee camp? Further, perhaps the adversity will evolve as well (i.e., incremental changes to legal, economic, and/or social constraints). How do the constructs of our model co-evolve over an extended period?

Finally, despite the persistence of the adversity and little hope for a change in the near future, a change may occur nonetheless. How do individuals respond to the disruption of the status quo that has maintained substantial adversity over a long period? Does the nature of (informal) entrepreneurial action, integration activities, and multiple identity configurations foster or obstruct resilience to the change (i.e., the new environment)? Future research has the opportunity to investigate the adaptation process and resilience outcomes arising from changes to contexts that have experienced an extended period of adversity. Furthermore, we focused on the resilience outcomes for the individual entrepreneur, but future research can explore the influence of entrepreneurial action in the context of substantial and persistent adversity on the resilience of the refugee community and perhaps also on the entrepreneurial action and resilience of the host community.

In conclusion, we set out to study how entrepreneurial action influences resilience outcomes in a context of substantial and persistent adversity - the refugee entrepreneur context-yet in constructing our model, we found a series of recursive relationships. Therefore, to understand resilience outcomes, we need to reflect (1) not only on entrepreneurial action but also on how resilience outcomes facilitate entrepreneurial action, (2) not only on how interactions with others facilitate resilience outcomes but also on how resilience outcomes influence these interaction activities, and (3) not only how multiple identities trigger entrepreneurial action for resilience outcomes but also on how resilience outcomes (through integration activities) influence the nature of an entrepreneur's multiple identities. Therefore, the overall message is that just as entrepreneurial action and identity are important for understanding resilience outcomes, resilience outcomes are important for understanding entrepreneurial action and identity in the context of substantial and persistent adversity. Although there are a number of literatures that investigate adversity, entrepreneurial action, and resilience, none do so in an integrative recursive fashion in the context of substantial and persistent adversity. Our study of refugee entrepreneurs offers a different perspective of resilience, a perspective of resilience under substantial and persistent adversity. 
Appendix A. Details of Entrepreneurs and their Businesses

\begin{tabular}{|c|c|c|}
\hline Name & Respondent information & Enterprise information \\
\hline \multirow[t]{3}{*}{ Ahmad I. (male) } & Lives: Beirut (in a camp)[;Age: 36 & Type of Entrepreneur: Social Entrepreneur \\
\hline & $\begin{array}{l}\text { Yrs as Refugee: } 36 ; \text { Generation refugee: 2nd; Identity: Palestinian; } \\
\text { Marital status: to a Syrian woman }\end{array}$ & $\begin{array}{l}\text { Enterprise description: Drug and alcohol rehabilitation center and } \\
\text { industrial kitchen }\end{array}$ \\
\hline & & $\begin{array}{l}\text { Enterprise age: } 7 \text { yrs.; Employees: Camp Palestinians \& Syrians } \\
\text { Business Registration: Not registered }\end{array}$ \\
\hline \multirow{4}{*}{$\begin{array}{l}\text { Ahmad M. } \\
\text { (male) }\end{array}$} & Lives: Sidon; Age: 28 ; & Type of Entrepreneur: Filmmaker \\
\hline & Yrs as Refugee: 28; Generation refugee: 3rd; & Enterprise description: Film production and photography \\
\hline & Identity: Palestinian, Lebanized; & Enterprise age: 6 yrs.; Employees: 0 \\
\hline & Marital status: Engaged to a Lebanese-British & Business Registration: Registered (but has not renewed) \\
\hline \multirow{3}{*}{$\begin{array}{l}\text { Amina A. } \\
\text { (female) }\end{array}$} & Lives: Sidon; Age: 41 & Type of Entrepreneur: Social Entrepreneur \\
\hline & $\begin{array}{l}\text { Yrs as Refugee: } 41 \text { (in Lebanon19); Generation refugee: 2nd; } \\
\text { Identity: Palestinian }\end{array}$ & $\begin{array}{l}\text { Enterprise description: Teaching institute, media organization, and } \\
\text { stitching business }\end{array}$ \\
\hline & Marital status: to a Palestinian man (4 child.) & $\begin{array}{l}\text { Enterprise age: } 19 \text { yrs.; Employees: } 2 \text { Lebanese \& } 4 \text { Palestinian } \\
\text { Business Registration: Registered (Lebanese non-profit) }\end{array}$ \\
\hline \multirow{4}{*}{$\begin{array}{l}\text { Atallah S. } \\
\text { (male) }\end{array}$} & Lives: Beirut; Age: 31; & Type of Entrepreneur: Copywriter \\
\hline & Yrs as Refugee: 31 ; Generation refugee: 3rd; & Enterprise description: Copywriting and Arabic content creation \\
\hline & Identity: Palestinian, Lebanized (mother is Leb.) & Enterprise age: 2 yrs.; Employees: 0 \\
\hline & Marital status: Single & Business Registration: Not registered \\
\hline \multirow{4}{*}{$\begin{array}{l}\text { Bayan B. } \\
\text { (female) }\end{array}$} & Lives: Beirut; Age: 36; & Type of Entrepreneur: Graphic Designer \\
\hline & Yrs as Refugee: 36; Generation refugee: 3rd; & Enterprise description: Graphic design and animation \\
\hline & Identity: Palestinian, Lebanized & Enterprise age: 6 yrs.; Employees: 0, outsources work \\
\hline & Marital status: Single & Business Registration: Not registered \\
\hline \multirow{4}{*}{$\begin{array}{l}\text { Ghazi G. } \\
\text { (male) }\end{array}$} & Lives: Beirut; Age: 56; & Type of Entrepreneur: Photographer \\
\hline & Yrs as Refugee: $56 ;$ Generation refugee: $2 \mathrm{nd}$; & Enterprise description: Corporate and events photography \\
\hline & Identity: Palestinian, Lebanized & Enterprise age: 26 yrs.; Employees: 0 \\
\hline & Marital status: to a Palestinian, 2 children & Business Registration: Not registered \\
\hline \multirow{4}{*}{$\begin{array}{l}\text { Ihab N. } \\
\text { (male) }\end{array}$} & Lives: South of Beirut; Age: 44; & Type of Entrepreneur: Construction Subcontractor \\
\hline & Yrs as Refugee: 44; Generation refugee: 2nd; & Enterprise description: Building construction \\
\hline & Identity: Palestinian - Lebanized & Enterprise age: 20 yrs.; Employees: Hires daily for projects \\
\hline & Marital status: to Palestinian woman (7 children) & Business Registration: Not registered \\
\hline \multirow{5}{*}{$\begin{array}{l}\text { Iman K. } \\
\quad \text { (female) }\end{array}$} & Lives: Tyr (in a gathering); Age: 22 & Type of Entrepreneur: Food Caterer \\
\hline & Yrs as Refugee: 22; Generation refugee: 3rd; & Enterprise description: Catering \\
\hline & Identity: Palestinian - Lebanized & Enterprise age: $1 \mathrm{yr}$ \\
\hline & Marital status: Single & Employees: 0 \\
\hline & & Business Registration: Not registered \\
\hline \multirow{4}{*}{$\begin{array}{l}\text { Khaled Y. } \\
\text { (male) }\end{array}$} & Lives: Tripoli (in a camp); Age: 53 ; & Type of Entrepreneur: Accountant \\
\hline & Yrs as Refugee: 53; Generation refugee: $2 \mathrm{nd}$; & Enterprise description: Accounting \\
\hline & Identity: Palestinian & Employees: 0 \\
\hline & Marital status: to a Palestinian ( 3 child.) & Business Registration: Not registered \\
\hline \multirow{4}{*}{$\begin{array}{l}\text { Maher S. } \\
\text { (male) }\end{array}$} & Lives: Beirut; Age: 37; & Type of Entrepreneur: Filmmaker and Graphic Designer \\
\hline & Yrs as Refugee: 37; Generation refugee: 3rd; & Enterprise description: Film production and graphic design \\
\hline & Identity: Palestinian, Lebanized & Enterprise age: 6 yrs.; Employees: 3 unregistered employees \\
\hline & Marital status: Single & Business Registration: Not registered \\
\hline \multirow{4}{*}{$\begin{array}{l}\text { Mariam S. } \\
\quad \text { (female) }\end{array}$} & Lives: Beirut (in a camp); Age: 46 & Type of Entrepreneur: Social Entrepreneur \\
\hline & Yrs as Refugee: 46 ; Generation refugee: $2 \mathrm{nd}$; & Enterprise description: Women's empowerment through catering \\
\hline & Identity: Palestinian & Enterprise age: 12 yrs.; Employees: 1 full-time, others part-time \\
\hline & Marital status: Single & Business Registration: Registered (Lebanese NGO) \\
\hline \multirow{4}{*}{$\begin{array}{l}\text { Marwan M. } \\
\text { (male) }\end{array}$} & Lives: Southern suburbs of Beirut; Age: 34 & Type of Entrepreneur: Music Entrepreneur \\
\hline & Yrs as Refugee: 34; Generation refugee: 3rd; & Enterprise description: Music composing, disk jockeying, and audio \\
\hline & Identity: Palestinian-Lebanese, Lebanized & equipment rental \\
\hline & Marital status: Single & $\begin{array}{l}\text { Enterprise age: } 8 \text { yrs.; Employees: } 0 \\
\text { Business Registration: Not registered }\end{array}$ \\
\hline \multirow{4}{*}{$\begin{array}{l}\text { Mohammad A. } \\
\text { (male) }\end{array}$} & Lives: Chouf District; Age: 42; & Type of Entrepreneur: Furniture Designer and Carpenter \\
\hline & Yrs as Refugee: 42; Generation refugee: $3 \mathrm{rd}$; & Enterprise description: Custom furniture design and carpentry \\
\hline & Identity: Palestinian, Lebanized & Enterprise age: 18 yrs.; Employees: hires daily workers (2-8) \\
\hline & Marital status: Married to a Lebanese (2 children) & Business Registration: Not registered \\
\hline \multirow{4}{*}{$\begin{array}{l}\text { Mohammad D. } \\
\text { (male) }\end{array}$} & Lives: Sidon; Age: 25; & Type of Entrepreneur: Engineering Subcontractor \\
\hline & Yrs as Refugee: 25; Generation refugee: 3rd; & Enterprise description: Structural engineering and design \\
\hline & Identity: Palestinian & Enterprise age: 2 yrs.; Employees: 0 \\
\hline & Marital status: Single & Business Registration: Registered (private limited company) \\
\hline \multirow{4}{*}{$\begin{array}{r}\text { Mourad A. } \\
\text { (male) }\end{array}$} & Lives: Tripoli; Generation refugee: $3 \mathrm{rd}$ & Type of Entrepreneur: Food Trader \\
\hline & Age: 28; Yrs as Refugee: 28 & Enterprise description: Trade of Fresh and Preserved Fish \\
\hline & Identity: Palestinian, Lebanized & Enterprise age: 1 yr; Employees: daily workers (from camp) \\
\hline & Marital status: Single & Business Registration: Not registered (in process of registering) \\
\hline \multirow{4}{*}{$\begin{array}{r}\text { Mustafa A. } \\
\text { (male) }\end{array}$} & Lives: Chouf District; Age: 30; & Type of Entrepreneur: Printing Entrepreneur \\
\hline & Yrs as Refugee: 30; Generation refugee: $3 \mathrm{rd}$; & Enterprise description: Advertising and print works \\
\hline & Identity: Palestinian, Lebanized & Enterprise age: 14 yrs.; Employees: Syrian employees \\
\hline & Marital status: to a Lebanese woman (2 children) & Business Registration: Not registered \\
\hline
\end{tabular}


Nabil H. (male)

Nader S. (male)

Nasser K. (male)

Nisreen I. (female)

Pierre K. (male)

Salah El Din A. (male)

Salim S. (male)

Sara M. (female)

Waad $\mathrm{H}$. (female)

Wafaa I.

(female) Yrs as Refugee: 39; Generation refugee: 2nd;

Lives: Beqaa Valley (in a gathering); Age: 34; Yrs as Refugee: 34; Generation refugee: 3rd Identity: Palestinian, Lebanized Marital status: a Palestinian from Syria (1 child)

\section{Lives: Tyr; Age: 41;}

Yrs as Refugee: 41; Generation refugee: 2nd; Identity: Palestinian

Marital status: to a Palestinian (4 children)

Lives: Near Tyr (in a camp); Age: 42;

Yrs as Refugee: 42; Generation refugee: 2nd; Identity: Palestinian

Marital status: to a Palestinian (4 children)

Lives: Beirut; Age: 42;

Yrs as Refugee: 42; Generation refugee: 2nd;

Identity: Palestinian, Lebanized

Marital status: Single

Lives: Northern suburbs Beirut (camp); Age: 30; Yrs as Refugee: 30; Generation refugee: 2 nd;

Identity: Palestinian, Lebanized

Marital status: to a Lebanese woman (2 children)

Yrs as Refugee: 23; Generation refugee: 3rd;

Identity: Palestinian - Lebanized

Marital status: Single

Age: 51; Yrs as Refugee: 51

Identity: Palestinian, Lebanized

Marital status: to a Palestinian

Lives: Sidon; Age: 21;

Yrs as Refugee: 21; Generation refugee: 3rd; Identity: Palestinian - Lebanized

Marital status: Single

Lives: Sidon; Age: 21;

Yrs as Refugee: 21; Generation refugee: 3rd; Identity: Palestinian

Marital status: Single

Lives: Sidon; Age: 39; Identity: Palestinian

Marital status: to a Palestinian (2 children)

Wissam K. (male)

Lives: Northern suburbs Beirut (camp); Age: 46; Yrs as Refugee: 46; Generation refugee: 3rd;

Identity: Palestinian-Lebanese, Lebanized

Marital status: to a Palestinian (4 children)

Zafer K. Lives: Sidon; Age: 53;

(male) Yrs as Refugee: 53; Generation refugee: 2nd;

Identity: Palestinian

Marital status: to a Palestinian (3 children)
Type of Entrepreneur: Social Entrepreneur

Enterprise description: Sports and cultural center in a gathering

Enterprise age: 5 years; Employees: All volunteers

Business Registration: Not Registered

Type of Entrepreneur: Social Entrepreneur

Enterprise description: Social and cultural center in a camp

Enterprise age: 6 yrs.; Employees: temporary hires, volunteers

Business Registration: Not registered

Type of Entrepreneur: Photographer and Videographer

Enterprise description: Photography and video production

Enterprise age: 22 yrs.; Employees: 0

Business Registration: Not registered

Type of Entrepreneur: Beauty and hairdressing entrepreneur

Enterprise description: Women's Hairdressing Salon

Enterprise age: 15 yrs.; Employees: 1 full-time, freelancers

Business Registration: Registered (Establishment)

Type of Entrepreneur: Accountant

Enterprise description: Accounting

Enterprise age: Did not reveal; Employees: 0

Business Registration: Not registered

Type of Entrepreneur: Printing Entrepreneur

Enterprise description: T-shirt printing

Enterprise age: 1 yr; Employees: 0

Business Registration: Not registered

Type of Entrepreneur: Mobile Phone Repair Specialist

Enterprise description: Mobile phone repair shop

Enterprise age: 19 yrs.; Employees: 0

Registration: Not registered

Type of Entrepreneur: Food Caterer

Enterprise description: Food catering

Enterprise age: $1 \mathrm{yr}$; Employees: 0

Business Registration: Not registered

Type of Entrepreneur: Creative Writer and Translator

Enterprise description: Writer, translator, \& poet

Enterprise age: 3 yrs.; Employees: 0

Business Registration: Not registered

Type of Entrepreneur: Social Entrepreneur

Enterprise description: Women's empowerment through catering and trade of preserved foods

Enterprise age: 2 yrs.; Employees: 1 Lebanese, 3 Palestinians Business Registration: Registered (NGO/cooperative)

Type of Entrepreneur: Printing Entrepreneur

Enterprise description: Printing press and advertising fixtures Enterprise age: 8 yrs.; Employees: 2 Palestinians, 1 Egyptian Business Registration: Registered (private limited company) Type of Entrepreneur: Social Entrepreneur

Enterprise description: Social and cultural center in a camp

Enterprise age: 6 yrs.; Employees: 10 full-time employees, 4 part-timers,

5 teachers, 4 trainers, and 20 volunteers.

Business Registration: Registered (Lebanese NGO)

The names have been changed to protect anonymity.

\section{References}

Aldrich, D.P., 2012. Building Resilience: Social Capital in Post-Disaster Recovery. University of Chicago Press, Chicago, Il.

Aldrich, D.P., Meyer, M.A., 2015. Social capital and community resilience. Am. Behav. Sci. 59 (2), 254-269.

Aleinikoff, T.A., 2015. From Dependence to Self-Reliance: Changing the Paradigm in Protracted Refugee. Policy Brief. Migration Policy Institute, Washington D.C. Al-Khatib, I.A., Arafat, R.N., Musmar, M., 2005. Housing environment and women's health in a Palestinian refugee camp. Int. J. Environ. Health Res. 15 (3), 181-191. Al-Natour, S., 1997. The legal status of Palestinians in Lebanon. J. Refug. Stud. 10 (3), 360-377.

Amabile, T.M., Barsade, S.G., Mueller, J.S., Staw, B.M., 2005. Affect and creativity at work. Adm. Sci. Q. 50 (3), $367-403$.

Anderies, J.M., Walker, B.H., Kinzig, A.P., 2006. Fifteen weddings and a funeral: case studies and resilience-based management. Ecol. Soc. 11 (1), 21.

Anderson, J., Markides, C., 2007. Strategic innovation at the base of the pyramid. MIT Sloan Manag. Rev. 49 (1), $83-88$.

Ashforth, B., 2000. Role Transitions in Organizational Life: An Identity-Based Perspective. Routledge.

Ashforth, B.E., Kreiner, G.E., Fugate, M., 2000. All in a day's work: boundaries and micro role transitions. Acad. Manag. Rev. 25 (3), $472-491$.

Berglund, K., Gaddefors, J., Lindgren, M., 2016. Provoking identities: entrepreneurship and emerging identity positions in rural development. Entrep. Reg. Dev. 28 (12), 76-96.

Betancourt, T.S., Abdi, S., Ito, B.S., Lilienthal, G.M., Agalab, N., Ellis, H., 2015. We left one war and came to another: resource loss, acculturative stress, and caregiver-child relationships in Somali refugee families. Cult. Divers. Ethn. Minor. Psychol. 21 (1), 114-125.

Biernacki, P., Waldorf, D., 1981. Snowball sampling: problems and techniques of chain referral sampling. Sociol. Methods Res. 10 (2), $141-163$.

Bigley, G.A., Roberts, K.H., 2001. The incident command system: high-reliability organizing for complex and volatile task environments. Acad. Manag. J. 44 (6), 
1281-1299.

Bizri, R.M., 2017. Refugee-entrepreneurship: A social capital perspective. Entrepreneurship \& Regional Development 29 (9-10), 847-868.

Bonanno, G.A., 2004. Loss, trauma, and human resilience: have we underestimated the human capacity to thrive after extremely aversive events? Am. Psychol. 59 (1), 20-28.

Bonanno, G.A., 2005. Resilience in the face of potential trauma. Curr. Dir. Psychol. Sci. 14 (3), 135-138.

Bonanno, G.A., Moskowitz, J.T., Papa, A., Folkman, S., 2005. Resilience to loss in bereaved spouses, bereaved parents, and bereaved gay men. J. Pers. Soc. Psychol. 88 (5), 827-843.

Bonanno, G.A., Galea, S., Bucciarelli, A., Vlahov, D., 2006. Psychological resilience after disaster: New York City in the aftermath of the September 11th terrorist attack. Psychol. Sci. 17 (3), 181-186.

Bonanno, G.A., Brewin, C.R., Kaniasty, K., Greca, A.M.L., 2010. Weighing the costs of disaster: consequences, risks, and resilience in individuals, families, and communities. Psychol. Sci. Public Interest 11 (1), 1-49.

Bradley, R.H., Corwyn, R.F., 2002. Socioeconomic status and child development. Annu. Rev. Psychol. 53 (1), $371-399$.

Branzei, O., Abdelnour, S., 2010. Another day, another dollar: Enterprise resilience under terrorism in developing countries. J. Int. Bus. Stud. 41 (5), 804-825.

Brook, A.T., Garcia, J., Fleming, M.A., 2008. The effects of multiple identities on psychological well-being. Personal. Soc. Psychol. Bull. 34 (12), 1588-1600.

Browne, K., 2005. Snowball sampling: using social networks to research non-heterosexual women. International Journal Social Research Methodology 8 (1), 47-60.

Bullough, A., Renko, M., Myatt, T., 2014. Danger zone entrepreneurs: the importance of resilience and self-efficacy for entrepreneurial intentions. Entrepreneurship

Theory and Practice 38 (3), 473-499.

Burke, P.J., 1980. The self: measurement requirements from an interactionist perspective. Soc. Psychol. Q. 43 (1), $18-29$.

Burke, P.J., Reitzes, D.C., 1981. The link between identity and role performance. Soc. Psychol. Q. 44 (2), 83-92.

Burke, P.J., Stets, J.E., 2009. Identity Theory. Oxford University Press, Oxford, U.K.

Cameron, K., Dutton, J., 2003. Positive Organizational Scholarship: Foundations of a New Discipline. Berrett-Koehler Publishers.

Cardon, M.S., Wincent, J., Singh, J., Drnovsek, M., 2009. The nature and experience of entrepreneurial passion. Acad. Manag. Rev. 34 (3), $511-532$.

Chaaban, J., Salti, N., Ghattas, H., Irani, A., Ismail, T., Batlouni, L., 2016. Survey on the Socioeconomic Status of Palestine Refugees in Lebanon 2015. Report published by the American University of Beirut (AUB) and the United Nations Relief and Works Agency for Palestine Refugees in the Near East (UNRWA) UNRWA, Beirut. Charmaz, K., 2006. Constructing grounded theory: A practical guide through qualitative analysis. Sage.

Conroy, S.A., O'Leary-Kelly, A.M., 2014. Letting go and moving on: work-related identity loss and recovery. Acad. Manag. Rev. 39 (1), 67-87.

Corbin, J.S., Strauss, A., 1998. Basics of qualitative research: Techniques and procedures for developing grounded theory.

Cutler, S.J., 2016. Refugee crisis and re-emergence of forgotten infections in Europe. Clin. Microbiol. Infect. 22 (1), 8-9.

de Roon-Cassini, T.A., Mancini, A.D., Rusch, M.D., Bonanno, G.A., 2010. Psychopathology and resilience following traumatic injury: a latent growth mixture model analysis. Rehabilitation Psychology 55 (1), 1-11.

Dewald, J., Bowen, F., 2010. Storm clouds and silver linings: responding to disruptive innovations through cognitive resilience. Entrepreneurship Theory and Practice 34 (1), 197-218.

Diez Roux, A.V., Mair, C., 2010. Neighborhoods and health. Ann. N. Y. Acad. Sci. 1186 (1), 125-145.

Drabek, T.E., McEntire, D.A., 2003. Emergent phenomena and the sociology of disaster: lessons, trends and opportunities from the research literature. Disaster Prevention and Management: An International Journal 12 (2), 97-112.

Dutton, J.E., Glynn, M.A., Spreitzer, G., 2008. Positive organizational scholarship. In: The Sage Handbook of Organizational Behavior. vol. 1. pp. 693-712.

El-Nashif, N., El-Khoury, S., 2012. Palestinian Employment in Lebanon: Labour Force Survey among Palestinian Refugees Living in Camps and Gatherings in Lebanon. International Labour Organization (ILO) and Committee for the Employment of Palestinian Refugees, Beirut. L.

Folkman, S., 2013. Stress: appraisal and coping. In: Gellman, M.D., Turner, J.R. (Eds.), Encyclopedia of Behavioral Medicine. Springer New York, NY, pp. 1913-1915.

Fong, R., Busch, N.B., Armour, M., Heffron, L.C., Chanmugam, A., 2007. Pathways to self-sufficiency: successful entrepreneurship for refugees. J. Ethn. Cult. Divers. Soc. Work 16 (1-2), 127-159.

Fredrickson, B.L., 1998. Cultivated emotions: parental socialization of positive emotions and self-conscious emotions. Psychol. Inq. 9 (4), 279-281.

Fredrickson, B.L., Joiner, T., 2002. Positive emotions trigger upward spirals toward emotional well-being. Psychol. Sci. 13 (2), $172-175$.

Freiling, J., Harima, A., 2019. Refugee entrepreneurship: learning from case evidence. In: Refugee Entrepreneurship. Palgrave Macmillan, Cham, pp. 255-277.

Gecas, V., 1982. The self-concept. Annu. Rev. Sociol. 8 (1), 1-33.

George, G., 2005. Slack resources and the performance of privately held firms. Acad. Manag. J. 48 (4), $661-676$.

Grant, A.M., Wade-Benzoni, K.A., 2009. The hot and cool of death awareness at work: mortality cues, aging, and self-protective and prosocial motivations. Acad. Manag. Rev. 34 (4), 600-622.

Haddad, S., Jamali, D., 2003. The politics of refugees' non integration: the dilemma of Palestinians in Lebanon. J. Int. Migr. Integr. 4 (1), 1-22.

Halabi, Z., 2004. Exclusion and identity in Lebanon's Palestine refugee camps: a story of sustained conflict. Environ. Urban. 16 (2), $39-48$.

Halme, M., Lindeman, S., Linna, P., 2012. Innovation for inclusive business: Intrapreneurial bricolage in multinational corporations. J. Manag. Stud. 49 (4), $743-784$.

Hanafi, S., Tiltnes, A., 2008. The employability of Palestinian professionals in Lebanon: constraints and transgression. Knowledge, Work and Society 5 (1), 1-15.

Hanafi, S., Chaaban, J., Seyfert, K., 2012. Social exclusion of Palestinian refugees in Lebanon: reflections on the mechanisms that cement their persistent poverty. Refug. Surv. Q. 31 (1), 34-53.

Haynie, J.M., Shepherd, D., 2011. Toward a theory of discontinuous career transition: investigating career transitions necessitated by traumatic life events. J. Appl. Psychol. 96 (3), 501.

Hobfoll, S.E., 1989. Conservation of resources: a new attempt at conceptualizing stress. Am. Psychol. 44 (3), $513-524$.

Hobfoll, S.E., 2011. Conservation of resource caravans and engaged settings. J. Occup. Organ. Psychol. 84 (1), $116-122$.

Hooberman, J., Rosenfeld, B., Rasmussen, A., Keller, A., 2010. Resilience in trauma-exposed refugees: the moderating effect of coping style on resilience variables. Am. J. Orthopsychiatry 80 (4), 557-563.

Howells, K., Fletcher, D., 2015. Sink or swim: adversity-and growth-related experiences in Olympic swimming champions. Psychol. Sport Exerc. 16, 37-48.

Hutchinson, M., Dorsett, P., 2012. What does the literature say about resilience in refugee people? Implications for practice. J. Soc. Incl. 3 (2), 55-78.

Ibarra, H., 1999. Provisional selves: experimenting with image and identity in professional adaptation. Adm. Sci. Q. 44 (4), $764-791$.

International Labor Organization, and Committee for the Employment of Palestinian Refugees in Lebanon, 2011. Labour Force Survey among Palestinian Refugees Living in Camps and Gatherings in Lebanon, 2011. ILO, Beirut, Lebanon.

Jack, S.L., Anderson, A.R., 2002. The effects of embeddedness on the entrepreneurial process. J. Bus. Ventur. 17 (5), $467-487$.

Janssen, M.A., Bodin, Ö., Anderies, J.M., Elmqvist, T., Ernstson, H., McAllister, R.R., Olsson, P., Ryan, P., 2006. Toward a network perspective of the study of resilience in social-ecological systems. Ecol. Soc. 11 (1), 1-20.

Keyes, C.L.M., Lopez, S.J., 2002. Toward a science of mental health: positive directions in diagnosis and interventions. In: Snyder, C.R., Lopez, S.J. (Eds.), Handbook of Positive Psychology. Oxford University Press, New York, pp. 45-59.

Khalil, A., 2011. Socioeconomic rights of Palestinian refugees in Arab countries. International Journal of Refugee Law 23 (4), $680-719$.

Khoury, L. 2017 December 16 Palestinians in Lebanon: it's like living in a prison. Retrieved from http://www.aljazeera.com/news/2017/12/palestinians-lebanonliving-prison-171215114602518.html.

Knight, R.M., 1983. Entrepreneurship in Canada. Journal of Small Business 1, 9-15.

Knudsen, A., 2009. Widening the protection gap: the 'politics of citizenship' for Palestinian refugees in Lebanon, 1948-2008. J. Refug. Stud. 22 (1), 51-73.

Korsgaard, S., Anderson, A., Gaddefors, J., 2016. Entrepreneurship as re-sourcing: towards a new image of entrepreneurship in a time of financial, economic and sociospatial crisis. Journal of Enterprising Communities: People and Places in the Global Economy 10 (2), 178-202.

Korsgaard, S., Ferguson, R., Gaddefors, J., 2015. The best of both worlds: how rural entrepreneurs use placial embeddedness and strategic networks to create opportunities. Entrep. Reg. Dev. 27 (9-10), 574-598. 
Korsgaard, S., Müller, S., Tanvig, H.W., 2015. Rural entrepreneurship or entrepreneurship in the rural-between place and space. Int. J. Entrep. Behav. Res. 21 (1), $5-26$.

Lanivich, S.E., 2015. The rich entrepreneur: using conservation of resources theory in contexts of uncertainty. Entrepreneurship Theory and Practice 39 (4), 863-894.

Lebanese Palestinian Dialogue Committee, 2018. The Population and Housing Census in Palestinian Camps and Gatherings - 2017, Key Findings Report (Population, Buildings and Housing Units): Beirut, Lebanon.

Lengnick-Hall, C.A., Beck, T.E., 2005. Adaptive fit versus robust transformation: how organizations respond to environmental change. J. Manag. 31 (5), $738-757$. Locke, K., 2001. Grounded theory in management research. Sage, London.

Luthar, S.S., Cicchetti, D., Becker, B., 2000. The construct of resilience: a critical evaluation and guidelines for future work. Child Dev. 71 (3), 543-562.

Van Maanen, J. 1979. Reclaiming qualitative methods for organizational research: a preface. Adm. Sci. Q., 24(4): 520-526.

Maitlis, S., 2009. Who am I now? Sensemaking and identity in posttraumatic growth. In: Roberts, L.M., Dutton, J.E. (Eds.), Exploring Positive Identities and Organizations: Building a Theoretical and Research Foundation. Psychology Press, New York, NY, pp. 47-76.

Masten, A.S., Reed, M.G.J., 2002. Resilience in development. In: Handbook of Positive Psychology. vol. 74. pp. 88.

Matthews, K.A., Gallo, L.C., 2011. Psychological perspectives on pathways linking socioeconomic status and physical health. Annu. Rev. Psychol. 62, 501-530.

McElwee, G., 2006. Farmers as entrepreneurs: developing competitive skills. J. Dev. Entrep. 11 (3), 187-206.

McGregor, L.S., Melvin, G.A., Newman, L.K., 2015. Differential accounts of refugee and resettlement experiences in youth with high and low levels of posttraumatic stress disorder (PTSD) symptomatology: a mixed-methods investigation. Am. J. Orthopsychiatry 85 (4), 371-381.

McMullen, J.S., Shepherd, D.A., 2006. Entrepreneurial action and the role of uncertainty in the theory of the entrepreneur. Acad. Manag. Rev. 31 (1), $132-152$.

Mone, M.A., McKinley, W., Barker, V.L., 1998. Organizational decline and innovation: a contingency framework. Acad. Manag. Rev. 23 (1), 115-132.

Monin, P., Noorderhaven, N., Vaara, E., Kroon, D., 2013. Giving sense to and making sense of justice in postmerger integration. Acad. Manag. J. 56 (1), $256-284$.

Murnieks, C.Y., Mosakowski, E., Cardon, M.S., 2014. Pathways of passion: identity centrality, passion, and behavior among entrepreneurs. J. Manag. 40 (6), $1583-1606$.

Nag, R., Corley, K.G., Gioia, D.A., 2007. The intersection of organizational identity, knowledge, and practice: Attempting strategic change via knowledge grafting. Acad. Manag. J. 50 (4), 821-847.

Palalić, R., Dana, L.P., Ramadani, V., 2019. Refugee entrepreneurship: a case study from the Sultanate of Oman. In: Refugee Entrepreneurship. Palgrave Macmillan, Cham, pp. 207-219.

Papadopoulos, R.K., 2001. Refugee families: issues of systemic supervision. J. Fam. Ther. 23 (4), 405-422.

Peirce, C.S., Hartshorne, C., Weiss, P., Burks, A., 1958. Collected Papers of Charles Sanders Peirce. vols. 1-8 Cambridge University Press, Harvard, MA.

Perez, D.F., Nie, J.X., Ardern, C.I., Radhu, N., Ritvo, P., 2013. Impact of participant incentives and direct and snowball sampling on survey response rate in an ethnically diverse community: results from a pilot study of physical activity and the built environment. J. Immigr. Minor. Health 15 (1), $207-214$.

Petriglieri, J.L., 2011. Under threat: responses to and the consequences of threats to individuals' identities. Acad. Manag. Rev. 36 (4), 641-662.

Piccardi, L., Boccia, M., Colangeli, S., Bianchini, F., Marano, A., Giannini, A.M., ... D'Amico, S., 2016. Neuro-functional alterations due to PTSD after environmental disasters: fMRI evidence and clinical suggestions. Journal of Psychopathology 22, 165-171.

Powell, E.E., Baker, T., 2014. It's what you make of it: founder identity and enacting strategic responses to adversity. Acad. Manag. J. 57 (5), $1406-1433$.

Powell, E.E., Baker, T., 2017. In the beginning: identity processes and organizing in multi-founder nascent ventures. Acad. Manag. J. 60 (6), $2381-2414$.

Powell, S., Rosner, R., Butollo, W., Tedeschi, R.G., Calhoun, L.G., 2003. Posttraumatic growth after war: a study with former refugees and displaced people in Sarajevo. J. Clin. Psychol. 59 (1), 71-83.

Prahalad, C.K., 2006. The Fortune at the Bottom of the Pyramid. Pearson Education India.

Pratt, M.G., Foreman, P.O., 2000. Classifying managerial responses to multiple organizational identities. Acad. Manag. Rev. 25 (1), $18-42$.

Rahmandad, H., Repenning, N., 2016. Capability erosion dynamics. Strateg. Manag. J. 37 (4), 649-672.

Ray, D., 1993. Open and bounded entrepreneurship. J. Small Bus. Entrep. 10 (3), 91-100.

Refai, D., Haloub, R., Lever, J., 2018. Contextualizing entrepreneurial identity among Syrian refugees in Jordan: The emergence of a destabilized habitus? Int. J. Entrep. Innov. 19 (4), 250-260.

Roberts, K.H., 1990. Some characteristics of one type of high reliability organization. Organ. Sci. 1 (2), $160-176$.

Ryff, C.D., 1989. Happiness is everything, or is it? Explorations on the meaning of psychological well-being. J. Pers. Soc. Psychol. 57 (6), $1069-1081$.

Ryff, C.D., Keyes, C.L.M., 1995. The structure of psychological well-being revisited. J. Pers. Soc. Psychol. 69 (4), $719-727$.

Sachs, J., 2008. The end of poverty: economic possibilities for our time. Eur. J. Dent. Educ. 12 (s1), 17-21.

Saghieh, N., Nammour, K., 2015. Labor rights of Palestinian refugees in Lebanon: access to liberal professions. In: Policy Dialogues Series - Lebanese-Palestinian Relations No. 2/2015 Common Space Initiative for Shared Knowledge and Consensus Building, Beirut.

Said, W., 1999. The Palestinians in Lebanon: the rights of the victims of the Palestinian-Israeli peace process. Columbia Human Rights Law Review 30 , $315-357$.

Segal, S.P., Khoury, V.C., Salah, R., Ghannam, J., 2018. Contributors to screening positive for mental illness in Lebanon's Shatila Palestinian refugee camp. J. Nerv. Ment. Dis. 206 (1), 46-51.

Seligman, M.E., Csikszentmihalyi, M., 2014. Positive psychology: an introduction. In: Flow and the Foundations of Positive Psychology. Springer, Dordrecht, pp. 279-298.

Shane, S.A., 2008. The Illusions of Entrepreneurship: The Costly Myths that Entrepreneurs, Investors, and Policy Makers Live by. Yale University Press.

Sheldon, K.M., King, L., 2001. Why positive psychology is necessary. Am. Psychol. 56 (3), 216.

Shepherd, D., Haynie, J.M., 2009. Family business, identity conflict, and an expedited entrepreneurial process: a process of resolving identity conflict. Entrepreneurship Theory and Practice 33 (6), 1245-1264.

Shepherd, D.A., Williams, T.A., 2014. Local venturing as compassion organizing in the aftermath of a natural disaster: the role of localness and community in reducing suffering. J. Manag. Stud. 51 (6), 952-994.

Shepherd, D.A., Williams, T.A., 2018. Hitting rock bottom after job loss: bouncing back to create a new positive work identity. Acad. Manag. Rev. 43 (1), 28-49.

Shiblak, A., 1996. Residency status and civil rights of Palestine refugees in Arab countries. J. Palest. Stud. 25 (3), $36-45$.

Soykoek, S., Mall, V., Nehring, I., Henningsen, P., Aberl, S., 2017. Post-traumatic stress disorder in Syrian children of a German refugee camp. Lancet 389 (10072), 903-904.

Ssenyonga, J., Owens, V., Olema, D.K., 2013. Posttraumatic growth, resilience, and posttraumatic stress disorder (PTSD) among refugees. Procedia Soc. Behav. Sci. 82, 144-148.

Steel, Z., Silove, D., Bird, K., McGorry, P., Mohan, P., 1999. Pathways from war trauma to posttraumatic stress symptoms among Tamil asylum seekers, refugees, and immigrants. J. Trauma. Stress. 12 (3), 421-435.

Steel, Z., Silove, D., Phan, T., Bauman, A., 2002. Long-term effect of psychological trauma on the mental health of Vietnamese refugees resettled in Australia: a population-based study. Lancet 360 (9339), 1056-1062.

Strauss, A., Corbin, J., 1990. Basics of qualitative research. Sage publications.

Stryker, S., 1980. Symbolic Interactionism: A Social Structural Version. Benjamin-Cummings Publishing.

Stryker, S., Burke, P.J., 2000. The past, present, and future of an identity theory. Soc. Psychol. Q. 63, $284-297$.

Suddaby, R., 2006. What Grounded Theory is Not (Editorial). Acad. Manag. J. 49, 633-642.

Suleiman, J., 2006. Marginalised Community: The Case of Palestinian Refugees in Lebanon. Development Research Centre on Migration, Globalization and Poverty, University of Sussex.

Suleiman, J., 2010. Trapped Refugees: The Case of Palestinians in Lebanon. No Refuge: Palestinians in Lebanon. RSC Working Paper Series, vol. 64. pp. 7-18. https:// www.rsc.ox.ac.uk/files/files-1/wp64-no-refuge-2010.pdf.

Sutcliffe, K.M., Vogus, T.J., 2003. Organizing for resilience. In: Roberts, L.M., Dutton, J.E. (Eds.), Exploring Positive Identities and Organizations: Building a Theoretical and Research Foundation. Psychology Press, New York, NY, pp. 94-110. 
Tay, A.K., Silove, D., 2017. The ADAPT model: bridging the gap between psychosocial and individual responses to mass violence and refugee trauma. Epidemiology and Psychiatric Sciences 26 (2), 142-145.

Thoits, P.A., 1983. Multiple identities and psychological well-being: a reformulation and test of the social isolation hypothesis. Am. Sociol. Rev. 48, 174-187.

Thoits, P.A., 1986. Multiple identities: examining gender and marital status differences in distress. Am. Sociol. Rev. $259-272$.

Thomas, J.B., Clark, S.M., Gioia, D.A., 1993. Strategic sensemaking and organizational performance: linkages among scanning, interpretation, action, and outcomes. Acad. Manag. J. 36 (2), 239-270.

Tian, Y., Fan, X., 2014. Adversity quotients, environmental variables and career adaptability in student nurses. J. Vocat. Behav. 85 (3), $251-257$.

Van der Vegt, G.S., Essens, P., Wahlström, M., George, G., 2015. Managing risk and resilience. Acad. Manag. J. 58 (4), 971-980.

Vogus, T.J., Sutcliffe, K.M., 2007, October. Organizational resilience: towards a theory and research agenda. In: Systems, Man and Cybernetics, 2007. ISIC. IEEF International Conference on. IEEE, pp. 3418-3422.

Vough, H.C., Caza, B.B., 2017. Where do I go from here? Sensemaking and the construction of growth-based stories in the wake of denied promotions. Acad. Manag. Rev. 42 (1), 103-128.

Wauters, B., Lambrecht, J., 2006. Refugee entrepreneurship in Belgium: potential and practice. Int. Entrep. Manag. J. 2 (4), 509-525.

Wauters, B., Lambrecht, J., 2008. Barriers to refugee entrepreneurship in Belgium: towards an explanatory model. J. Ethn. Migr. Stud. 34 (6), $895-915$.

Wayne, J.H., Butts, M.M., Casper, W.J., Allen, T.D., 2017. In search of balance: a conceptual and empirical integration of multiple meanings of work-family balance. Pers. Psychol. 70 (1), 167-210.

Weick, K.E., 1993. The collapse of sensemaking in organizations: the Mann Gulch disaster. Adm. Sci. Q. 38, 628-652.

Weick, K., Sutcliffe, K.M., Obstfeld, D., 1999. Organizing for high reliability: Processes of collective mindfulness. In: Sutton, R.I., Staw, B.M. (Eds.), Research in Organizational Behavior. JAI Press, Stamford, CT, pp. 81-123.

Weick, K.E., Sutcliffe, K.M., Obstfeld, D., 2008. Organizing for high reliability: processes of collective mindfulness. Crisis Management 3 (1), $31-66$.

Welter, F., 2011. Contextualizing entrepreneurship-conceptual challenges and ways forward. Entrepreneurship theory and Practice 35 (1), $165-184$.

Welter, F., Baker, T., Audretsch, D.B., Gartner, W.B., 2017. Everyday entrepreneurship-a call for entrepreneurship research to embrace entrepreneurial diversity. Enterp. Theory Pract. 41 (3), 311-321.

Wildavsky, A., 1988. Searching for Safety. University of California Press, Berkeley, CA.

Wildavsky, A., 2017. Anticipation versus resilience. In: Searching for Safety. Routledge, New York, NY, pp. 97-126.

Williams, T.A., Shepherd, D.A., 2016a. Building resilience or providing sustenance: different paths of emergent ventures in the aftermath of the Haiti earthquake. Acad. Manag. J. 59 (6), 2069-2102.

Williams, T.A., Shepherd, D.A., 2016b. Victim entrepreneurs doing well by doing good: venture creation and well-being in the aftermath of a resource shock. J. Bus. Ventur. 31 (4), 365-387.

Williams, T.A., Gruber, D.A., Sutcliffe, K.M., Shepherd, D.A., Zhao, E.Y., 2017. Organizational response to adversity: fusing crisis management and resilience research streams. Acad. Manag. Ann. 11 (2), 733-769.

Youssef, C.M., Luthans, F., 2007. Positive organizational behavior in the workplace: the impact of hope, optimism, and resilience. J. Manag. 33 (5), 774-800. 